\title{
Multinationality and performance literature: a critical review and future research agenda
}

Article

Accepted Version

Nguyen, Q. T. K. (2017) Multinationality and performance literature: a critical review and future research agenda.

Management International Review, 57 (3). pp. 311-347. ISSN 1861-8901 doi: https://doi.org/10.1007/s11575-016-0290-y Available at https://centaur.reading.ac.uk/61031/

It is advisable to refer to the publisher's version if you intend to cite from the work. See Guidance on citing.

To link to this article DOI: http://dx.doi.org/10.1007/s11575-016-0290-y

Publisher: Gabler Verlag

All outputs in CentAUR are protected by Intellectual Property Rights law, including copyright law. Copyright and IPR is retained by the creators or other copyright holders. Terms and conditions for use of this material are defined in the End User Agreement.

www.reading.ac.uk/centaur 
Central Archive at the University of Reading

Reading's research outputs online 


\section{MULTINATIONALITY AND PERFORMANCE LITERATURE:}

\section{A CRITICAL REVIEW AND FUTURE RESEARCH AGENDA}

\section{Quyen T.K. Nguyen (Ph.D) (Corresponding author)}

Lecturer in International Business and Strategy

Henley Business School, International Business and Strategy, University of Reading, Whiteknights Campus, Reading, England RG6 6UD.

\section{E-mail: t.k.q.nguyen@henley.ac.uk}

\section{Abstract}

- The literature on the relationship between the degree of multinationality (M) and performance $(\mathrm{P})$ in the context of multinational enterprises (MNEs) has attracted a large volume of scholarly research in the past 50 years. Yet, the conclusions concerning the nature of M-P relationship and the theoretical foundations vary greatly, thus call for a critical review and assessment.

- We adopt an original inter-disciplinary approach by integrating international business, finance, and accounting perspectives to provide a comprehensive and critical review of the literature. We examine 135 articles in 39 leading scholarly journals and classic books published during the period 1960-2015. We use an inductive approach and a qualitative content analysis methodology for our review.

- Our analysis shows that the literature has been built upon a wide variety of theoretical perspectives. The majority of previous studies predominantly examine the relationship between $\mathrm{M}$ and $\mathrm{P}$. Thus, we review the theoretical conceptualization and measurement of $\mathrm{M}, \mathrm{P}$, the findings on M-P relationships, methodologies, and geographic focus. We identify six key inconsistencies in the existing research, which cause ambiguity in the relevant findings. We make eight recommendations for future research directions to 
address these inconsistencies. Thus, our analysis contributes to the central debate in this research field.

Key words: multinationality (M); performance (P); M-P relationships; internalization theory; FSAs/CSAs framework; accounting perspectives (IAS38; IFRS8 and FASB131). 


\section{MULTINATIONALITY AND PERFORMANCE LITERATURE:}

\section{A CRITICAL REVIEW AND FUTURE RESEARCH AGENDA}

\section{Introduction}

The research on the relationship between the degree of multinationality $(\mathrm{M})$ and performance $(\mathrm{P})$ of the multinational enterprise $(\mathrm{MNE})$ has generated an enormous number of studies in the international business (IB) literature in the past 50 years. The majority of previous studies focus predominantly on testing the effects of multinationality on firm performance, rather than examining the impact of internal factors of the firm and external business environments of home and host countries on its performance. Despite all efforts, this research stream is still the subject of endless debate due to the inconclusive empirical results with different functional forms and shapes, ranging from linear positive, negative, U-, inverted $\mathrm{U}_{-}, \mathrm{J}_{-}$, inverted J-, S-, inverted S-shaped and those with no relationship. Bowe et al. (2010) maintain that prior research has failed to discover a consistently signed relationship. Glaum and Oesterle (2007) argue that the M-P debate has generated more questions than concrete answers. Unsurprisingly, a number of IB scholars have cast doubt on the valid theoretical rationale for such a generalizable M-P relationship (Dess et al., 1995; Hennart, 2007, 2011; Verbeke et al., 2009; Verbeke and Brugman, 2009; Verbeke and Forootan, 2012).

This literature has accelerated to a point whereby there are now meta-analysis studies (Bausch and Krist, 2007; Kirca et al., 2011; Kirca et al., 2012; Kirca et al., 2012; Palich et al., 2000; Yang and Driffeld, 2012); literature review studies (Annavarjula and Beldona, 2000; Cardinal et al., 2011; Hill et al., 2006; Li, 2007; Matysiak and Bausch, 2012; Oesterle and Richta, 2013; Ramaswamy, 1992; Sullivan, 1994a,b), and conceptual papers (Glaum and Oesterle, 2007; Hennart, 2007, 2011; Verbeke and Brugman, 2009; Contractor, 2007, 2012; Hult, 2011; Verbeke and Forootan, 2012). 
The M-P relationship is among the key topics in the field of IB research. We believe that the time is ripe to conduct reviews, meta-analyses, and conceptual works, which help us to understand the achievements and limitations of the extant literature. It is important to identify generalizable relationships, to detect the contradictions and potential reasons in the empirical literature, and to provide suggestions incorporating both theory and methodology to advance the literature.

Our study differs from existing literature review articles in several major areas. First, we adopt an innovative and original inter-disciplinary approach by incorporating IB, finance theories and accounting perspectives in our work. We demonstrate the need for such an integrated approach in our critical literature review, in our analysis of theoretical concepts and measurements, as well as in our analysis of the empirical findings of the existing literature, and in our suggestions for future research. Thus, we provide a new fresh way of thinking about the old issues of the M-P literature. Our work is a timely response to calls by finance scholars to integrate contemporary finance into IB research (Agmon, 2006; Bowe et al., 2010; Oxelheim et al., 2001, 2012), because such an inter-disciplinary approach will enrich the literature.

Second, we examine 135 articles in 39 leading journals and classic books published between 1960 and 2015, which have been identified from numerous disciplines and the fields of international business, strategic management, finance, financial economics, international management, financial management and accounting, and marketing. We aim to consolidate previous research findings, and to provide an overall picture across these domains and disciplines, because there is a lack of integration of the existing literature in these related fields (Kirca et al., 2012). We use an inductive approach and conduct a qualitative content analysis, which has been recognized in management research as a research tool for integrating and expanding the bases of knowledge on a specific research topic (Duriau et al, 
2007). This approach enables researchers to analyze the contents of the literature through careful procedures, such as examining data sources, identifying research themes, and leads to suggestions for methodological refinements. Qualitative content analysis is also well suited to contributing to the development of theory and for synthesizing empirical research over a variety of disciplines and studies. Overall, our study advances previous qualitative literature review papers (Annavarjula and Beldona, 2000; Hitt et al., 2006; Li, 2007; Cardinal et al., 2011; Matysiak and Bausch, 2012; Oesterle and Richta, 2013), which are based on smaller samples focus on a narrower, more limited set of issues.

Third, we not only present the state of the art M-P literature but also provide a critical evaluation, in which we identify six key inconsistencies in the existing literature. We discuss the essential results and findings of our review. Specifically, we find that previous studies use a wide variety of theories, or multiple theories to advocate for a particular model. The inconsistencies are also found in the theoretical conceptualization and measurements of $\mathrm{M}, \mathrm{P}$ and M-P relationships, an omission of risk-return trade-off, a deficiency of diversity in geographic focus (i.e. the majority of studies use the United States firm datasets), and a lack of cross-country analysis and comparative studies. To clearly demonstrate our findings from a critical literature review, we have prepared an in-depth analysis of 50 representative articles including dependent, independent, control and moderating variables (if any), sample size, statistical techniques, and findings with different functional forms and shapes. Due to space constraints, they are not presented here.

Finally, we provide eight practical and solution-focused suggestions for new directions of future research after we present our thorough review of previous meta-analysis, literature review and conceptual papers. Our recommendations are theoretically rigorous and empirically testable. Specifically, we recommend that future research focus on the interrelationship between firm-specific advantages (FSAs) and performance, i.e. that FSAs are the 
key driver of a firm's performance. A proportion of profits are then retained (retained earnings) to finance reinvestment in the continuous development, creation and generation of FSAs. This assures the sustainable expansion and growth of the firm. We suggest that researchers consider applying international accounting standards, such as IFRS8-Operating Segments and the US GAAP FASB 131-Disclosures about Segments of an Enterprise and Related Information to examine the relationship between geographic segments and performance. This is strongly related to the literature of regional strategy and the performance of the MNE and its foreign subsidiaries (Rugman and Verbeke, 2004; Rugman, 2000, 2005; Oh \& Rugman, 2014; Nguyen, 2014, 2015a). In addition, we suggest that it is particularly important to isolate the effects of the performance of home country operations from international operations by examining the return on home assets (ROHA) and the return on foreign assets (ROFA) separately. This approach advances the current literature, which focuses on examining the relationship between the degree of multinationality and the return on total assets (ROTA). We recommend that future research considers using alternative measures of value-based performance and incorporates finance factors in the research design. We also emphasize the need for diverse research settings, with research conducted in other countries than the United States, as well as the need for comparative studies. Finally, future research might examine this phenomenon from a lower unit of analysis by using a subsidiarylevel perspective.

\section{Focus of the Study}

We examine what and how theoretical concepts and approaches have been applied to explain the phenomenon of the M-P relationship as we attempt to analyze the main results and inconsistencies in the existing literature. To achieve this objective, we critically assess publications on this research stream in top journals and classic books. We aim at answering three closely interrelated questions: 
1. How does the existing literature conceptualize the M-P relationship?

2. What inconsistencies in this literature can be identified?

3. How can we advance our knowledge in this research stream?

\section{Methodology}

In order to address our research questions, we use an inductive approach and a qualitative content analysis (Duriau et al, 2007). This methodology has been adopted in previous literature review studies by Jormanainen and Koveshnikov (2012), and Stahl and Tung (2015). Such an approach allows us to focus on investigating how this phenomenon has been addressed in top journals and classic books, how the topic has been examined, and what are the main findings to date. We follow the suggestions by Duriau et al. (2007). Our research design consists of several methodological steps taken in a systematic manner to ensure the reliability of the analysis. This enables us to use clear definitions of the concepts, research area, database for analysis, selection of texts to be analyzed and interpretation of the results (Duriau et al. 2007; Jormanainen and Koveshnikov, 2012).

\section{Research Area and Selection of Database and Journals}

We follow Duriau et al (2007) and Kirca et al. (2011) in our methodological approach to define the database for the analysis, i.e. which database and which journals to select for reviewing. In the first stage, we use the database of Business Source Complete by EBSCO Industries, Inc. to search for articles. This is one of the most comprehensive databases covering full-text articles in scholarly journals and books. In the second stage, we proceed by carefully examining articles issue-by-issue in leading journals in the fields of IB, general management, strategic management, marketing, economics, finance, financial economics, financial management and accounting. These include Journal of International Business Studies (JIBS), Strategic Management Journal (SMJ), Academy of Management Journal, Management International Review (MIR), International Business Review (IBR), Journal of 
Business Research (JBR), Journal of World Business (JWB), Multinational Business Review (MBR), Global Strategy Journal (GSJ), British Journal of Management, Journal of Management, Journal of International Management, Asia Pacific Management Journal, Journal of Finance, Corporate Finance Review, Journal of Financial and Quantitative Analysis, European Journal of Management, and others. These journals are recognized as top publications with high impact factors by the ISI Web of knowledge database and Association Business School Journal Quality Guide. In the third stage, we examine reference sections of all previous major meta-analysis and literature review articles which have been published on the topic. This careful procedure ensures to identify any studies which we might have overlooked in the previous two stages (Kirca et al., 2011).

\section{Selection of Text for Analysis}

The next step of the methodological procedure is to select articles and books to be reviewed. We decide to include only published full-length research articles and classic books. We exclude unpublished thesis, dissertations, and working papers. The reason we include only published studies is that they are subject to a rigorous peer-review process (Jormanainen and Koveshnikov, 2012). Furthermore, future research can refer to these articles from our reference list, as they are publicly available unlike unpublished works. Our selection approach here is consistent with previous studies by Duriau et al. (2007), Jormanainen and Koveshnikov (2012) and Stahl and Tung (2015). However, it is slightly different from Kirca et al. (2011), which includes both published and unpublished studies. The period of selected publication covers from 1960 with the first publication by Hymer (1960) to 2015 (inclusive). Our intention is to provide a comprehensive overview of the literature covering important contributions to the field.

To select articles from the database and journals, we have chosen a number of key words in line with our specific focus on the M-P relationship in the context of the MNE. We focus on 
MNEs only as they expand internationally by establishing a network of foreign subsidiaries (i.e. engaging in foreign direct investment (FDI) activities) rather than exporting or licensing (Buckley and Casson, 1976; Hennart, 1982; Rugman, 1981). We exclude articles on the relationship between internationalization (I) and performance (P) by exporting of small and medium sized enterprises (SMEs), foreign market involvement by exporting of born-global firms and international new ventures (INVs), and the internationalization of top management teams (TMT), as these topics belong to other research streams.

Our approach of article selection differs from most previous literature reviews, meta-analysis, and conceptual articles, as these include studies of SMEs, MNEs, INVs, and TMT. In the internationalization process, SMEs see exporting as offering potential extra sales and may use a local agent or distributor, or may choose to export directly to a particular foreign market. However, the depth of SMEs' involvement and their resource commitment to expand to foreign markets by exporting is low relative to MNEs with value-adding FDI activities, except for those subsidiaries located in tax havens. From the perspective of internalization theory, MNEs must carefully weigh firm-specific advantages (FSAs) and home and host country-specific advantages (CSAs) in their strategic decisions about foreign market involvement (Rugman, 1981; Rugman \& Collinson, 2012).

We provide a clear definition of an MNE. This helps conceptually justify our selection of articles for this review. An MNE is defined as a company headquartered in one country, but having operations in other countries (Rugman, 1981). Specifically, an MNE must have the ratio of foreign sales to total sales (FS/FS) of at least 10 percent and three foreign subsidiaries (Rugman, 1981). The threshold of FS/TS at 10 percent comes from the international accounting standards, such as IFRS8-Operating Segments and the US GAAP FASB 131Disclosures about Segments of an Enterprise and Related Information. 
The list of key search terms consists of references to the performance implications of international activities of the MNE. The search terms for multinationality include degree of multinationality, multinationality, degree of internationalization, internationalization, international expansion, international diversification, global diversification, geographic diversification, and international market diversification. The literature tends to use these concepts interchangeably, although they are not synonymous (Verbeke and Brugman, 2009). The search terms for firm performance include return on assets (ROA), return on equity (ROE), return on sales (ROS), Tobin's q, shareholder value, total shareholder return, sales growth, firm growth, risk adjusted return, scale efficiency, excess q, Jensen's alpha, Sharpe, Jensen and Treynor's measures, abnormal returns, excess value, market value, economic value added (EVA), and cash flow return on investment (CFROI).

With these lists of key search terms in mind, we go through all the articles shown in the database and journals. We read these articles carefully, in which we examine title, abstract, key words, introduction, conclusion, and journal outlets. We include both conceptual, empirical, literature review, and meta-analysis articles. The process identifies 128 articles in 39 leading journals, and seven (7) classic books, which makes a total sample of 135 studies. Table 1 presents our findings on the distribution of publication outlets.

Table 1

Table 2 reports the types of articles. These include 11 conceptual articles, 102 empirical articles, seven conceptual articles, nine literature reviews, and six meta-analysis articles.

\section{Table 2}

\section{Analysis}

We analyze these articles qualitatively (Welch et al, 2011). First, we focus on the manifest content of each article (Suddaby and Greenwood, 2005; Jormanainen and Koveshnikov, 2012). We read full contents of all these studies carefully and then we document them in an 
excel spreadsheet (Jormanainen and Koveshnikov, 2012). The information includes name of authors, year of publication, journals, theoretical perspectives, concepts and measurements, methodology in terms of data sources and geographic focus, control and moderating variables, key findings, and suggestions for future research proposed by these authors. We discussed our research process with an international business scholar with great expertise in this process and in the relevant literature.

Second, we analyze the latent content of each article (Suddaby and Greenwood, 2005) to ensure its direct contribution to the M-P relationship literature, and the core concepts ( $\mathrm{M}$ and $\mathrm{P})$ and relationships used to operationalize contributions ( $\mathrm{M}$ has a linear positive/negative/no/U-, inverted U-, J-, inverted J-, S- and inverted S-shaped performance implications). We read and code main points of the articles, theoretical perspectives, and conclusions.

Third, we analyze the content of the selected studies to outline what and how theoretical concepts and approaches have been developed. We examine the contributions in the existing literature in terms of consistency and validity, and summarize the results of our analysis in a framework (Figure 1).

\section{Figure 1}

\section{Findings and Discussion}

\section{Inconsistency 1: Theoretical foundations and overall empirical results}

Our analysis from the critical literature review shows that the literature has adopted a wide range of theoretical perspectives to advocate for a particular M-P relationship. These include internalization theory (Buckley and Casson, 1976; Hennart, 1982; Rugman, 1981); Dunning's eclectic paradigm (Dunning, 1985); the resource-based view of the firm (Wernerfelt, 1984; Barney, 1991; Teece, 1986; Teece et al., 1997); portfolio and diversification theory (Rugman, 1976); liability of internationalization (Hymer, 1960; Zaheer, 1995; Eden and Miller, 2001); 
incremental internationalization process and experiential learning (Johanson and Vahlne, 1977); and organizational evolution and organizational learning (Chandler, 1962; Tushman and Romanelli, 1985; Sullivan, 1994a,b; Contractor et al., 2003; Lu and Beamish, 2004). In addition, we find that a number of studies (Hitt et al., 2006; Contractor et al., 2003; Lu \& Beamish, 2004) use arguments from multiple theoretical perspectives to develop their conceptual models and hypotheses. However, Kirca et al., (2011) argue that this approach has created more ambiguity than clarification, as it becomes difficult to link the results from such an approach back to the confirmation, extension, or refutation of any particular theory.

In a related manner, empirical results vary greatly with different types of relationships. In subsequent sections, we provide a detailed review of the concepts and measurements of $\mathrm{M}, \mathrm{P}$ and empirical results on the M-P relationships. We discuss our findings analytically, and offer potentially plausible explanations of several inconsistencies in the conceptualization and measurement, which may cause mixed empirical results. We also identify some limitations in methodology (geographic focus and testing techniques).

\section{Our Analysis on Theoretical Foundation and Overall Empirical Findings}

An important element of our critical literature review is to identify the limitations of underlying assumptions, the inherent weaknesses of theoretical conceptualization, and measurements in the current literature. First, the major limitation of the M-P literature is the inability of researchers to ascertain to what extent multinationality leads to performance or performance leads to multinationality (Bowen, 2007; Verbeke and Brugman, 2009). All extant studies mainly examine one-way direction of causality of the effects of multinationality on firm performance. There is no study which examines the potential reverse effects of performance on multinationality. On the other hand, Jung \& Bansal (2009) test the relative performance on internationalization based on a behavioral perspective. They argue that management's decision to expand internationally may be made based on perceived firm 
performance. This is defined as firm performance relative to benchmarks by comparing it to its historical performance or its industry. However, they suggest that the perception of managers, which is susceptible to cognitive biases, plays a key role in firm internationalization and the availability of resources. One of their findings is that the stronger a firm performs relative to industry targets, the more likely it is that the firm expands internationally.

Second, another limitation of the literature is that prior research does not show a clear analysis of a firm's performance in its home country and international operations from its network of foreign subsidiaries, excepting Gestrin et al., (1998), Rugman et al., (2008), and Fisch and Zschoche (2011a, b). In other words, the underlying assumptions of the effects of multinationality on performance, which specify that a firm can achieve similar or greater profits in their foreign operations than in their home country, which justifies internationalization has not been substantiated convincingly in the majority of previous studies.

Third, we find that the number of empirical studies testing the relationship between FSAs and firm performance is much smaller than the large number of studies testing the M-P relationship. The studies by Rugman (1981), Morck and Yeung (1991), Rugman et al., (1985), Kirca et al. (2011), and Lee et al. (2015) are these few ones with a clear focus on FSAs as determinants of firm performance. The FSAs are the strengths or benefits specific to a firm as a result of contributions by its technology, brand, trademark, marketing, and managerial capabilities relative to its rivals (Rugman, 1981). Given that FSAs are prerequisites for a firm's internationalization and thus performance, this finding is puzzling.

\section{Inconsistency 2: Conceptualization and Measurements of Multinationality (M)}

According to Hennart (2011), multinationality refers to a firm's expansion beyond its domestic market into foreign countries. The degree of multinationality (M) is measured by a 
wide variety of constructs (Annavarjula and Beldona, 2000; Li, 2007, Hennart, 2011; Aggarwal et al., 2011), and multi-dimensional constructs (Sullivan 1994a, b). The most commonly used proxies include:

(a) Foreign market penetration: defined as the level of a firm's dependence on foreign markets (Hennart, 2011) as measured by the ratio of foreign sales to total sales (FS/TS) (Li, 2007; Hennart, 2011).

(b) Foreign production presence: defined as the degree to which a firm produces goods and services abroad (Hennart, 2011), as measured by the ratio of foreign assets to total assets (FA/TA), or the proportion of overseas subsidiaries to total subsidiaries (OS/TS), or foreign employees to total employees (FE/TE) (Kim et al., 1989).

(c) Foreign sales dispersion: defined as the dispersion of foreign sales based on segment data (Hennart, 2011).

(d) Country scope: defined as the number of foreign countries in which the firm operates (Hennart, 2011), as measured by a count-based number of foreign countries.

(e) Diversity of foreign countries entered: which is related to the external environment of cultural and institutional diversity (de Jong and van Houten, 2014).

(f) Attitudinal attributes: defined as top management's international experience and/or orientation (TMIO) (Sullivan, 1994a, b).

The measurements of multinationality can be broadly grouped into scale metrics (FS/TS, FA/TA, and FE/TE), and scope metrics (count-based number of foreign subsidiaries, and number of operating countries) (Rugman and Oh, 2011). The FS/TS ratio is the most frequently used proxy to measure the degree of multinationality $(\mathrm{M})$, because it is the basic metric showing the degree of foreign involvement. However, the FS/TS ratio, especially those studies using the Compustat database, suffers from one problem: this ratio includes 
exports by parent firms in home countries as well as sales by foreign subsidiaries in host countries (Hennart, 2011; Rugman and Oh, 2011; Wiersema and Bowen, 2011).

A number of studies have used sales-based entropy indices (Hitt et al., 1997; Kim, et al., 1989), multiple indicators (Tallman and Li, 1996), and a composite index of two or three indicators (Contractor et al., 2003; Li and Qian, 2005; Lu and Beamish, 2004; Lee et al., 2015) to refine the measurement of multinationality. The ratio FA/TA has not been frequently used (Geringer et al., 1989; Marthur et al., 2001). Daniels and Bracker (1989), Marthur et al., (2001), and Lee et al. (2015) use asset and sales coverage to measure multinationality.

Ramaswamy (1995), Tallman and Li (1996), and Yang et al. (2013) use a configuration measure of multinationality based on country scope. Michel and Shaked (1986) use countbased measures of number of foreign subsidiaries, and number of countries alongside international sales. Lu and Beamish (2004) use both country and subsidiary count, whereas Kim et al. (1989) employ a ratio of foreign employees to total employees (FE/TE).

Sullivan $(1994 \mathrm{a}, \mathrm{b})$ introduces the degree of internationalization composite index (DOI), comprising the ratio of FS/TS, FA/TA, OS/TS, top management's international experience (TMIE), and psychic dispersion of international operation (PDIO), which is a cultural variable discussed by Kogut and Singh (1988). The degree of internationalization is computed as follows: DOI = FSTS + FATA + TMIE + PDIO (Sullivan, 1994a). However, Ramaswamy et al. (1996) question the content validity of Sullivan's index (1994a). Rugman and Oh (2011) argue that Sullivan's (1994a) composite index of multinationality is simplistic, as it just adds together scale and scope metrics and confuses rather than clarifying matters. The cultural variable (psychic dispersion of international operation) in Sullivan's composite suffers from an inherent limitation, as it is related to ten theoretical problems in cross-cultural research identified by Shenkar (2001). The cultural composites by Hofstede (1983) and Kogut and Singh (1988) are among the most frequently used metrics in culture studies. 
However, the debate is still ongoing as to what constitutes culture, whether and how it could be measured, what is related, and what is relevant (McSweeney, 2002).

Tung and Verbeke (2010) advocate improving the quality of cross-cultural research beyond Hofstede and GLOBE (House et al., 2004; Hofstede, 2006). Hutzschenreuter and Voll (2008), and Hutzschenreuter et al., (2011) show that the measurements of macro-level distance, for example, in the cultural sphere, between home and host countries may be sometimes completely irrelevant. In the case of established MNEs, it is the additional distance that matters. The additional distance is the cultural distance between a newly entered host country and the country where the MNE is already established that exhibits the smallest distance with this new host country (see Verbeke and Brugman, 2009).

Verbeke and Brugman (2009) argue that there is an important difference between the degree of internationalization (DI) and the degree of international diversification (DID). The DI is related to the degree of the firm's international expansion, whereas the DID is related to the firm's geographic dispersion, which is affected by cultural and institutional environment diversity. These scholars suggest that activities in different host countries face idiosyncratic challenges, both in terms of external opportunities and threats, and the firm-level capability to profitably transfer, deploy and exploit the MNE's firm-specific advantages (FSAs). Verbeke and Brugman (2009) find that some studies have incorporated this distinction (Qian and Li, 2002; Goerzen and Beamish, 2003). Goerzen and Beamish (2003) suggest that the international asset dispersion and country environment diversity as two distinct dimensions of multinationality. Contractor et al. (2003) count the number of subsidiaries but do not determine how this measure is related to the number of countries. Lu and Beamish (2004) recognize the issue but do not present a diversification measure.

Yet, Rugman and Oh (2011) criticize the count-based scope metric of number of foreign countries because it provides simplistic and potentially misleading information about the 
foreign involvement of the firm. Rugman and Oh (2011) show that if a firm operates in one hundred countries, it would seem to be more multinational than a firm operating in two countries. However, if this is the case of a Canadian firm operating in a single large neighboring market, i.e. the United States, this firm is likely to have more foreign sales than another Canadian firm with operations in all other countries outside of the United States. Rugman and Oh (2011) maintain that the twenty largest Canadian firms generate on average about 80 percent of their foreign sales in the United States, with the remainder in rest of the world combined.

Rugman and Oh (2011) highlight a problem in the use of the scope measure. Basically, such a measure counts each country equally. Yet, for almost any firm, sales in a large market, such as the United States, Japan, Germany, and the UK will be of much greater significance than sales in smaller markets such as Jamaica, Luxemburg, and Kazakhstan. In other words, selling in a large number of small countries does not indicate that the firm is more multinational (see Rugman and Oh, 2011).

In addition, Hennart (2011) sharply criticizes the operationalization and the measurements of the degree of multinationality (M) as it does not match the theoretical arguments it has advanced. Hennart (2011) argues that the measurements of the degree of multinationality cannot be used to test arguments in the M-P literature, such as the ability to exploit intangibles, the ability to arbitrage, and external and internal costs of foreignness.

\section{Our Analysis on Conceptualization and Measurements of Multinationality}

One of the potential limitations of the variables of FA/TA, OS/TS, and FE/TE as proxies for international production is that they are not necessarily indicators of production activities. The FDI activities of MNEs could be focused on either distribution or R\&D only, without production activities. In addition, the count-based measures of the number of foreign subsidiaries and the number of host countries as proxies for the breadth or dispersion of 
internationalization have shortcomings. Specifically, they do not take into account the nature of foreign subsidiaries, whether or not they are really engaged in value-creating activities in accordance with Dunnings' four FDI motives of market-seeking, efficiency-seeking, natural resource-seeking and strategic asset-seeking (Dunning, 1998). They might be purely offshore financial centres, special purpose entities, or holding companies without any substantive economic and productive substance (UNCTAD, 2013).

In business reality, a number of foreign subsidiaries are established as offshoring financial centres (OFCs) to channel funds to and from third countries. They are located in countries, territories and jurisdictions with relatively low or no tax (a type of tax haven). For example, the top three destinations of FDI flows from the Russian Federation, which are Cyprus, the Netherlands and the British Virgin Islands, coincide with the top three investors in the Russian Federation. Such flows are more akin to domestic investments disguised as FDI. In other words, the bulk of inflows in OFCs consist of FDI in transit which is redirected to other countries (UNCTAD, 2013).

In a related manner, another type of offshore finance mechanism is special purpose entities (SPEs). SPEs are foreign affiliates which are established for a specific purpose (e.g. administration, management of foreign exchange, facilitation of financing of investment) or specific structure (e.g. holding companies). They tend to be established in low-tax countries which provide specific tax benefits for SPEs. They may not conduct any economic activity of their own and have very few employees. Luxembourg, the Netherlands, Hungary, Cyprus, Switzerland, Ireland, Portugal, Denmark, Mauritius, the British Virgin Islands, Cayman Islands, Bermuda and other low-tax jurisdictions are popular locations for SPEs (UNCTAD, 2013; Base Erosion and Profit Shifting, OECD, 2014). For example, Mauritius has concluded a double-taxation treaty with India and has attracted foreign firms, especially those owned by non-resident Indians, which establish holding companies in Mauritius to invest in India 
(UNCTAD, 2013). As a conduit for SPE FDI, Mauritius has become one of the largest FDI sources for India (UNCTAD, 2013).

Both OFCs and SPEs are created for tax benefit purposes rather than for value-creating activities (UNCTAD, 2013). For example, UK government has recently conducted inquiries into the UK operations of Google, Amazon, and Starbucks, which are all said to minimize their tax payments in the UK (The UK Parliament, Public Accounts Committee, 2012). Google runs its operations from Ireland; Amazon from Luxembourg; and Starbucks from the Netherlands. The three MNEs declare their profits consolidated across EU operations at the regional head offices, which are located in low-tax jurisdictions or tax havens (Rugman, 2013). In reality, the UNCTAD World Investment Report excludes OFCs and SPEs in reporting FDI flow data (UNCTAD, 2013).

We suggest that future research examine firms' annual reports, disclosure notes, and websites to collect information and a description of the nature of foreign operations rather than just rely on data extracted from large databases. The effects of these types of OFCs and SPEs should be controlled in future research design. Our suggestions here are consistent with Oesterle and Wolf (2011, page 21), who point out that "data from large databases usually do not paraphrase internal managerial aspects - and especially not the parameters controllable by managers — but, in most cases, only "surface characteristics" of the business firms".

Furthermore, we draw upon the accounting perspective to argue that the scale and spread of multinationality (M) can only be justified if it adds value to the firm through increased economies of scale and scope, and operational efficiency. If MNEs become too complex, the resulting problems of financial control and managerial motivation outweigh the advantages of larger size.

Inconsistency 3: Conceptualization and Measurements of Firm Performance (P) 
The firm's performance measurements are widely varied and different among studies ( $\mathrm{Li}$, 2007). The choice of performance measures is difficult and discretionary (Venkatraman and Ramanujam, 1986; Hult et al., 2008). The empirical literature has used both accounting-based and capital market-based performance measures. Each approach is associated with specific problems (Verbeke and Brugman, 2009). The most frequently used performance measures are as follows:

(a) Accounting-based performance indicators: return on total assets (ROTA=consolidated profit to total assets) (Grant, 1987; Grant et al., 1988; Lu and Beamish, 2004; Ruigrok et al., 2007; Contractor et al., 2007); return on total sales (ROTS=consolidated profit to total sales) (Tallman and Li, 1996; Delios and Beamish, 1999; Geringer et al., 2000; Capar and Kotabe, 2003; Contractor et al., 2007; Yang et al., 2013); return on equity (ROE=net profit after tax to owner's equity) (Qian, 1998; Rugman et al., 1985; Rugman, 1981; Thomas and Eden, 2004; Contractor et al., 2007; Fisch and Zschoche, 2011a).

(b) Operational performance indicators: sales growth (Grant, 1987; Zahra et al., 2000), market share, and product quality (Venkatraman and Ramanujam, 1986).

(c) Cost-efficiency indicators: the ratio of operating costs to sales (Gomes and Ramawasmy, 1999; Ruigrok and Wagner, 2003).

(d) Capital market-based indicators: Tobin's q, i.e. a ratio defined by market value of assets divided by their book value (Lu and Beamish, 2004; Whited, 2001; Rugman and Oh, 2010; Lee et al., 2015); risk adjusted return (Michel and Shaked, 1986; Buehner, 1987).

Verbeke and Brugman (2009) argue that Tobin's q is an inadequate performance measure as its underlying assumption is that markets are efficient, i.e. a firm's true value is accurately reflected in its market valuation. Verbeke and Brugman (2009) point out that in reality other parameters often appear to determine market valuation (Shiller, 2000), as demonstrated by the collapse of the world stock markets in 2007-2008. Verbeke and Brugman (2009) maintain 
that market performance may be a poor proxy of "true" performance, and that the difference between accounting and market-based performance measures may be idiosyncratic for each firm.

\section{Our Analysis on Performance Measurements}

We use the perspectives of accounting and value-based management to discuss the limitations of accounting-based performance measurements. They have shortcomings due to the possible managerial manipulation with profitability and changes in accounting systems (Morck and Yeung, 2009). They are retrospective in nature and they are unable to capture the MNE strategy manifested in its expected future profitability. They are generally poor measures of economic value added (EVA) (which is similar to the concept of economic profits by Severn and Laurence, 1974).

Furthermore, accounting conceptualization is a matter of concern. One of the main criticisms is related to the international accounting standard IAS38 Intangible assets, which deals with intangible assets, and R\&D expenditure (IAS38). "Intangible asset" is defined "as nonmonetary identifiable asset without physical substance. An asset is a resource that is controlled by the entity as the result of past purchase or self-creation and from which future economic benefits (inflows of cash and other assets) are expected" (IAS38). Examples of intangible assets are patented technology, trademarks, trade secrets, software, databases, internet domains, video and audio materials, customer base, licensing, royalty and standstill agreements, franchise agreements, and marketing rights (IAS38).

IAS38 requires an entity to recognize an intangible asset, whether purchased or self-created (at cost) if, and only if it is probable that the future economic benefits that are attributable to the asset will flow to the entity, and the cost of the asset can be measured reliably. This requirement applies whether an intangible asset is acquired externally or generated internally. The probability of future economic benefits must be based on reasonable assumptions about 
the conditions that will exist over the life of the asset. The probability recognition criterion is always considered to be satisfied for intangible assets that are acquired separately or in a business combination (IAS38).

Spending on research (R) does not meet the criteria of deferral under IAS38, so it is expensed as incurred. Development (D) costs are capitalized only after the technical and commercial feasibility of the asset for sale or use has been established, otherwise it is expensed (IAS38). Expertise is part of inherent corporate reputation, but as it cannot be valued reliably in a monetary amount, it is not recognized as an intangible asset in the balance sheet. Thus, a firm's R\&D and marketing activities reduce accounting-based profit, rather than increase them. This makes comparisons difficult between firms which invest substantially in R\&D and marketing, and those which do not.

We find that in the extant M-P literature, parent-level R\&D and marketing expenses over total sales are the two most frequently used proxies for firm-specific assets (Kirca et al., 2011). They are actually expenses, and thus decrease accounting-based profit. Alternatively, if $R \& D$ and marketing costs are considered as important inputs for the creation of outputs of patented technology and trademarks, etc. (which are true intangible assets by accounting definition), they should be adjusted in the economic profit (EVA), which is a more appropriate performance measure of the firm. However, none of the previous M-P empirical studies, meta-analysis, literature review and conceptual papers has considered these particularly important matters.

Indeed, there are arguments in the accounting literature that the traditional financial reporting model is inadequate for dealing with knowledge-based firms. It is possible that capital markets might undervalue the firm because the financial statements do not reflect the true effect of the firm's R\&D activities. Consequently, management of the firm often provides an overview of its previous year's operations and how the firm has fared in that time period. 
Management usually outlines its future strategy, goals, and directions for new projects in the section of management discussion analysis of the annual report. However, it should be noted that this document is not audited.

From the perspective of value-based management, there are two problems relating to accounting profit or loss (Martin and Petty, 2007; Ryan, 2011). First, accounting profit ignores the cost of equity capital. The computation of profit or loss only takes into account the cost of debt finance in the form of interest expense, which is tax deductible. However, the firm only generates wealth when it generates a return in excess of the return required by both equity and debt capital providers. Second, profits which are reported in accordance with accounting standards do not truly reflect the wealth which has been created (Martin and Petty, 2007; Ryan, 2011).

We find that none of the previous M-P empirical studies use EVA as a performance measure, probably because EVA data are not available in any large databases. The EVA measure can be computed in accordance with standard methods of adjusting accounting data, which will be discussed subsequently in our suggestion for future research.

On the other hand, despite the inherent limitations of accounting-based performance measurements, they are valid indicators when empirical studies attempt to measure the effectiveness of $R \& D$ expenditure and other intangible assets on firm performance. Furthermore, there might be differences between accounting-based and market-based performance measures concerning their time-dependent sensitivity and time-dependent effectiveness in exploiting FSAs. It is necessary to take a time-lag into account before the FSAs effects can be realized on the performance of the firm.

Finally, the criticisms by Verbeke \& Brugman (2009) on Tobin's q as a poor performance indicator in the case of shock events (e.g. financial crisis, etc.) can be addressed using statistical techniques. Specifically, future research is suggested to control for such effects by 
including dummy years. Another alternative solution is to exclude explicitly such years of crises from the investigated sample period.

\section{Inconsistency 4: Findings on the M-P Relationships}

\section{Positive Linear Relationship}

A number of studies provide empirical evidence to support the benefits of international expansion as argued by internalization theory, Dunning's eclectic paradigm, and the resource-based view of the firm (RBV). Previous studies find that a firm's performance is positively correlated with the degree of internationalization (Vernon, 1971; Benvignati, 1987;

Grant, 1987; Grant et al., 1988; Daniels and Brackers, 1989; Annavarjula et al., 2005; Rugman et al., 2008; Lee et al., 2015).

There are several reasons why increased multinationality should be linked to firm performance. These include maximizing its FSAs internally across borders (Rugman, 1981); risk reduction by international diversification (Rugman, 1976); benefits from economies of scale and scope (Buckley and Casson, 1979; Caves, 1996); reducing the impacts of domestic fluctuations by using foreign market outlets; taking advantage of factor cost differentials, and different tax regimes across multiple locations (Porter 1990; Jung, 1991; Contractor, 2012). Having multiple plants across several nations is said to increase profitability because it confers greater operational flexibility to shift production as factor costs, exchange rates or the business environment changes (Fisch and Zschoche, 2011b). Spreading common and central overheads over more and more nations, especially in $R \& D$ intensive industries (Kobrin, 1991; Tallman and Li, 1996; Contractor, 2012) is also likely to affect firm performance.

Rugman (1981) provides empirical evidence in which FSAs are important determinants of a firm's strategy and performance in accordance with the predictions of internalization theory. Similarly, Morck and Yeung (1991) find that the impact of spending on R\&D and advertising on market value increases with a firm's multinational scale, but that multinationality per se 
does not have any significant impact. Their results support internalization theory, which holds that intangible assets are necessary for FDI.

Lee et al. (2015) examine the valuation effects of multinationality on Korean firms to identify the role of multinationality in internalization theory. They find that multinationality and intangibility ( $R \& D$ and marketing) directly and independently influence firm value measured by Tobin's q, without any interference from each other. They do not find evidence to support a mediating effect of intangibility through multinationality on firm value nor a moderating effect of intangibility on firm value. Multinationality in Korean firms has never lost its importance, even during the global financial crisis in the year 2008.

In a related manner, Kirca et al. (2011) test the predictions of internalization theory on the role of firm-specific assets in the M-P literature, using a meta-analysis method. Specifically, they examine the direct effect of firm-specific assets on firm multinationality, the mediating

role of firm multinationality on the relationship between firm-specific assets and firm performance, the moderating role of firm-specific assets on the M-P relationship, and the M$\mathrm{P}$ relationship for R\&D intensive MNEs in manufacturing and service industries, for MNEs with high advertising intensity in service and manufacturing industries, and in high-tech and low-tech industries, advanced and developing economies. Through a meta-analysis of 120 independent samples reported in 111 studies, they find that multinationality provides an efficient mechanism to transfer their firm-specific assets to generate higher returns in foreign markets. Multinationality has intrinsic value above and beyond the intangible assets that firms possess after controlling for firms' international experience, age, size, and product diversification.

\section{Our Analysis on the Positive Relationship}

The linear positive model is built upon two underlying assumptions. The first assumption is that international opportunities are unlimited. However, this is highly improbable (Cardinal et 
al., 2011). The second assumption suggests that firms can manage their portfolios of international activities effectively and efficiently. However, this assumption has inherent shortcomings. In reality, headquarter managers often face bounded rationality, and bounded reliability problems (Verbeke, 2013) in managing and coordinating the increasing complex international operations, which might have a negative effect on a firm's performance. Our analysis is consistent with Penrose (1959), who theoretically develops the research proposition that the finite capacities of the firm's internally experienced managers limit the rate at which the firm can grow in a given period of time.

\section{Negative Relationship}

A number of scholars highlight the additional costs of doing business abroad due to the liability of foreignness (Hymer, 1960; Zaheer, 1995; Eden and Miller, 2001). Li (2007) finds that the literature provides evidence of "the liability of international diversification", especially in the finance literature (Christophe, 1997; Collins, 1990; Denis et al. 2002; Michel and Shaked, 1986). They emphasize the negative performance implications of multinationality. Siddharthan and Lall (1982) show that increasing the degree of internationalization and organizational environmental complexity may eventually exhaust managerial capacity. Difficulties arise from high information processing demands, which are compounded by cultural problems. Similarly, researchers in cross-cultural studies have identified communication, coordination and motivations problems from cultural diversity in the firm (Hofstede, 1983).

Studies by finance scholars find negative impacts of internationalization on firm performance (Click and Harrison, 2002; Denis et al., 2002). Click and Harrison (2002) use a dataset for the period from 1984 to 1997 to analyze different measures for market value. They find that internationalization is consistently associated with market value discount compared to domestic operations. Capital markets penalize corporate multinationality by putting a lower 
value on the equity of multinational corporations than on similar domestic corporations. The multinational discount is estimated to be in the range of 8.6 percent to 17.1 percent when Tobin's q is used for the analysis. Foreign assets are particularly associated with value destruction. In contrast, exporting from U.S. operations is associated with an export premium of approximately 3.9 percent, resulting from both a higher market value and a lower asset size. Then why do firms become MNEs? These scholars find that the proportion of a firm owned by management is inversely related to the likelihood that the firm is an MNE. Thus, they conclude that managers who do not own much of the firm may be engage in empire building for private gains at the expense of shareholders.

Similarly, Denis et al. (2002) argue that managers have an incentive to adopt and maintain value-reducing internationalization strategies, even if doing so reduces shareholders' wealth. This argument is deeply rooted in the agency theory, which is concerned with the opportunistic behavior of managers in investment due to information asymmetries (Ross, 1973). This can be a challenge for the MNE's governance system (Kim and Mauborgne, 1993). Furthermore, earlier studies also highlight the external costs of internationalization, such as financial and political risks. Financial risks, such as exchange rate fluctuations and inflation (Reeb et al., 1998) might offset the benefits of earnings stability derived from worldwide portfolio diversification. Political risks may arise when foreign governments enforce unanticipated change to the business environments, including fund remittance control, and expropriation (Boddewyn, 1988).

\section{Our Analysis on the Negative Relationship}

The negative model focuses mainly on the costs and risks of internationalization using parent-centric perspectives. However, it does not account sufficiently for benefits and returns on internationalization. In addition, it appears to underestimate subsidiary managers' capabilities to deal with the liability of foreignness, as they are the agents who run daily 
business. Subsidiary managers leverage their local knowledge and experience to develop sustainable strategies, and generate necessary new strategic sources and capabilities to overcome challenges of operations in host countries (Birkinshaw, 1996, 1997; 1999; Rugman and Verbeke, 2001; Nguyen and Rugman, 2015a, b). In reality, parent firms delegate a certain degree of autonomy to subsidiary managers (Birkinshaw and Hood, 1998; Roth and Morrison, 1992; McDonald et al., 2008), as this enables the latter to be responsive to local conditions, consumer tastes and preferences, build local legitimacy, and reduce problems of bounded rationality and bounded reliability of headquarter managers.

\section{Inverted J-Shaped Relationship}

A number of scholars recognize that the M-P relationship might be non-linear because firm performance is determined by the effects of both benefits and costs of internationalization (Li, 2007). From the perspective of incremental internationalization, Daniels and Bracker (1989), and Geringer et al. (1989) suggest there exists a period of expansionary growth where benefits exceed costs, and another period during which incremental costs exceed incremental benefits. The M-P relationship takes on an inverted J-curve form. Firms benefit from economies of scale, scope and locations when they expand initially into culturally and institutionally similar business environments, whereby the additional costs of doing business abroad are low (see Li, 2007). Similar consumer tastes, market systems, and institutional settings make the transfer of marketing, management, human resources, and technology less costly as it requires little or no adaptation. Likewise, there are not many adaptation requirements for organizational structures, leadership approaches, and corporate control mechanisms. Financial and political risks are low (Daniel and Bracker, 1989; Geringer et al., 1989; Gomes and Ramaswamy, 1999).

However, as firms expand into unfamiliar markets later on, administrative costs, such as governance costs, information processing costs, coordination costs, etc. increase substantially 
due to the challenges of external environment and internal organizational complexity (Ruigrok and Wagner 2003). Thus, there is a threshold of optimal degree of internationalization, in which performance maximum is identified at a degree of internationalization somewhere between 50-82 percent (Ruigrok and Wagner 2003). Performance appears to increase up to this critical zone, climax and then decrease monotonically (Daniels and Bracker, 1989; Geringer et al, 1989).

\section{Our Analysis on Inverted J-Shaped}

There are limitations of the inverted J-shaped model as it is built upon the internationalization theory. This theoretical model suggests firms expand first to geographically proximate and culturally and institutionally similar countries before entering into distant markets. However, in reality, firms from small countries tend to expand to distant countries when neighboring markets are small if they have a market-seeking motive for FDI. Another possibility is that firms need to go to distant countries when they seek strategic assets which are not available in proximate countries. Moreover, the model does not consider the possibility of mistakes, and slow learning during initial internationalization, which might lead to bankruptcy and divestures. Thus, the assumption, where firms attain a period of high performance in the initial internationalization (due to moving to neighboring markets) before their performance decreases (due to moving to distant markets), may not occur.

\section{U-Shaped and Inverted U-Shaped Relationship}

Hitt et al (1997) and Gomes and Ramaswamy (1999) draw upon the organizational learning theory to examine the M-P relationship. They hypothesize and empirically confirm that managerial experience with complex environments derived from mastering high product diversification provides the organization with knowledge for maintaining superior performance at high degrees of internationalization. Their findings indicate a positive linear relationship between internationalization and performance for firms with high product 
diversification, a standard U-form for non-diversified firms and an inverted U-shape for companies with moderate product diversification. The findings of a positive linear relationship for firms with long experience in managing high complexity suggests that if properly prepared, firms may not experience declining performance at all.

\section{Our Analysis on U-Shaped and Inverted U-Shaped Model}

There are limitations of the U-shaped and inverted U-shaped model. Firm can accumulate experience through learning from different sources, such as direct experience, previous decision outcomes, and observing the experiences of other firms (Gao et al., 2008). They develop new capabilities, refined routines, and the ability to adapt which are based on experience. They have gained knowledge in dealing with the challenges of internationalization and the ability to reduce the liability of foreignness (Henderson, 1999; Baum \& Shipilov, 2006). Consequently, the initial downward trend suggested by the Ushaped model may not occur when firms begin to enter foreign countries.

\section{S-Shaped and Inverted S-Shaped Relationship}

Sullivan (1994a) and Riahi-Belkaoui (1998) argue that the impact of internationalization on firm performance is delineated by an S-curve, which can be explained by the organizational evolution perspective and organizational learning theory. Lu and Beamish (2004) find a nonlinear horizontal S-curved relationship between geographic diversification and firm performance, because management learns to adapt to the new complexities of environment. A number of studies (Contractor et al, 2003; Lu and Beamish, 2004; Ruigrok et al., 2007; Bae et al., 2008; Rugman and Oh, 2010; Oh and Contractor, 2014) have provided more evidence for the S-curve relationship.

Contractor et al. (2003) develop a three-stage model of international expansion and the link between M-P. The first stage includes an initially negative effect of international expansion on performance shown by a negative slope (U-shaped relationship) due to the costs and 
barriers of initial internationalization, and the liability of foreignness. This is followed by a second stage of further internationalization with positive effects on performance represented in a positive slope where benefits of international expansion are now realized due to the achievement of economies of scale (Contractor, 2012). Finally, in the third stage excessive internationalization has a negative impact on performance shown by an inverted U-shaped relationship, which suggests that international expansion beyond an optimal level is again detrimental to performance and results in a negative slope.

Fisch and Zschoche (2011a) argue that the liability of foreignness and economies of scale are commonly used to substantiate the first stage of downward performance (falling) and the second state of upward performance (rising) of an S-shaped model between $\mathrm{M}$ and $\mathrm{P}$ relationship. These scholars apply the view of information costs (Casson, 1999), which is more inclusive than the view of transaction costs to substantiate the $S$-shaped curve. They use a dataset of 3,122 German MNEs provided by the Central Bank of Germany to empirically test their model. Their empirical findings suggest that economies of scale and the liability of foreignness are not closely correlated to the level of multinatinality. Furthermore, they find that the S-shaped influence of multinationality persists while economies of scale and the liability of foreignness exert an influence on performance as distinct factors.

On the other hand, Chiang and Yu (2005) find an inverted S-shaped relationship between internationalization and Taiwanese firms' performances for the period from 1998 to 2002 . They argue that the FDI activities of Taiwanese firms are concentrated in Asia (especially in Mainland China), which is both geographically and culturally proximate to Taiwan, so as to obtain the "market familiarity" advantage. The market familiarity facilitates the transfer of technology and managerial skills, but the continued expansion has to contend with the increasing complexity of global operation.

\section{Our Analysis of S-Shaped and Inverted S-shaped}


As with other models, the S-shaped model has limitations. If a firm's performance is poor following its initial international expansion, it might end up in bankruptcy. Consequently, the underlying assumption of an upward slope after a downward performance may not occur. In other words, there is no turning point from a downward to an upward performance. We illustrate our analysis with an example. Suntech Power was a Chinese solar energy solutions company with sales across the broad triad in 2011, having eight foreign subsidiaries, including one in the United States. However, it operated at loss. It could not service its debt obligations due to a heavy reliance on debt financing. In March 2013, Suntech was the first company from mainland China to default on its US bonds payment of US\$541 million (Morales \& Martin, 2013). Subsequently, Suntech's main unit, Wuxi Suntech Power Holdings Co., Ltd. was placed into insolvency as Chinese banks filed bankruptcy against Suntech (Goossens \& Doom, 2013; Sui-Lee, 2013). The company's American Depository Receipts were delisted from the New York Stock Exchange and placed on the over the counter exchange (for a detailed analysis, see Rugman et al., 2016).

\section{Other Contextual Factors}

Recent studies have taken into account the impact of MNE cultural diversity on the M-P relationship (de Jong and van Houton, 2014), and multinationality alignment and performance (MA-P) instead of the traditional M-P relationship (Powell, 2013). Powell (2013) suggests that rather than searching for a universal optimal level of $\mathrm{M}$ for all firms, firm-specific attributes should result in firm-specific optimal levels of multinationality. Drawing upon transaction cost and internalization theory, he argues that there will be different optimal levels of multinationality for individual firms, and if firms internalize foreign operations to an extent less than or greater than their individual optimal levels, transaction costs will increase and performance will decrease. He uses a dataset of the U.S. law firms and provides empirical evidence to support these hypotheses. However, this study 
has limitations in terms of generalizability as it is the U.S.-specific and the legal service industry-specific.

In a related manner, Kirca et al. (2012) use a meta-analysis method to examine the role of context in the M-P relationship. Their findings suggest that the effects of $\mathrm{M}$ on $\mathrm{P}$ depend on firm factors (firm size), type of M (depth of M measured by FS/TS and FA/TA and breath of M measured by number of countries), firm strategic motivations (revenue generation versus profit maximization), stage of internationalization (firms with the average FS/TS ratio of 10 percent and below are considered at early stage of internationalization; firms with an FS/TS ratio of 11 to 35 percent were assumed to be at intermediate stages; and firms with an FS/TS greater than 35 percent were categorized at the late stage of internationalization (Zahra et al., 2000; Zhou et al., 2007), industry factor (manufacturing versus service), and home country factor (developing versus developed).

\section{Our Analysis on Other Contextual Factors}

The measurement of the stage of internationalization and the related thresholds is a matter of concern. The FS/TS ratio includes exports by parent firms from home countries and sales by foreign subsidiaries in host countries. Firms can achieve the FS/TS ratio greater than 35 percent through exports, not necessarily through value-adding FDI activities by their foreign subsidiaries. For instance, Chinese firms could achieve a high FS/TS ratio through their exports from China. It does not mean that they are at a late stage of internationalization through FDI. We illustrate this point with an example. Ningbo Veken Elite Group is a Chinese firm specializing in textiles, yarn, fabric and garments. It has a FS/TS ratio of 53.20 percent through exports in 2012, but it has only three foreign subsidiaries mainly used to facilitate export sales from China to foreign markets (Ningbo Veken Elite Group, Annual report, 2012). In business reality, Chinese firms are in the early stage of internationalization 
through FDI following the Chinese government's "go global" policy in 2000 (see Rugman et al., 2016).

\section{Inconsistency 5: The Omission of Risk-Return Trade-off in Research Design}

Forty years ago, Rugman (1976) conducted pioneering work on risk reduction by considering international diversification in the field of IB research. He finds that it is possible for MNEs to reduce the risk of their profits by engaging in foreign operations. His empirical results show that foreign operations are inversely related to risk after controlling for size, industry classification, and other factors. This implies that international diversification offers MNEs significant risk reduction advantages which are not available to a non-MNE.

However, subsequent empirical M-P studies, excepting Hughes et al. (1975), Buehner (1987), Michel and Shaked (1986), and Kim et al. (1993), have largely neglected the risk-return relationship, which Verbeke and Brugman (2009) sharply criticize. In contrast, corporate finance focuses extensively on the risk and return trade-off. Bowe et al. (2010) maintain that a finance approach would agree with the risk-return theoretical argument made by Verbeke and Brugman (2009). Bowe et al. (2010) emphasize that consideration of risk is central to the appraisal of any investment decision. Basic finance theory advocates allocating resources to investment opportunities to equalize expected return per unit of risk (or risk adjusted return) across projects. From a theoretical viewpoint, a comparison of any measure of financial return, unadjusted for risk(s), across projects is difficult to justify. Bowe et al. (2010) argue that the omission of adequate controls for risk in many M-P studies implies that the methodology is deeply flawed.

\section{Our Analysis on the Omissions of Risk-Return Trade-off}

The omission of the risk-return trade-off may be attributed to various possible explanations. First, the underlying assumption that there is a relationship between $\mathrm{M}$ and $\mathrm{P}$ has become an established norm in the IB literature. Consequently, the majority of previous studies do not 
look at the phenomenon from a different angle, such as to bring finance factors into the IB research design. Unsurprisingly, there are very few studies using financial returns (adjusted for risks) in the performance assessment, excepting Hughes et al. (1975), Buehner (1987), Michel and Shaked (1986), and Kim et al. (1993). In a related manner, a large number of studies use ROE as a key performance indicator but do not control for the effects of financial leverage in the capital structure of the firm, e.g. debt-to-equity ratio, excepting Delios and Beamish (1999), Marther et al. (2001), and Thomas and Eden (2004). The higher the level of debt, the higher the ROE, but it also implies higher bankruptcy risks, financial distress and cost of capital for the firm.

Second, empirical work requires data collection from multiple sources (e.g. firm data, home and host country risk data, etc.), which are contingent upon access and availability. Third, reading and conducting content analysis of firms' annual reports to obtain an in-depth understanding of their risk management strategies is a time-consuming and demanding task for researchers in comparison with the common practice of extracting data from large databases.

\section{Inconsistency 6: Methodologies and Geographic Focus}

Our analysis of methodological approaches adopted in the selected articles is important, because it shows how rigorous and generalizable the findings and conclusions are. Our findings are that 100 percent of empirical studies in our sample use quantitative methods and regression techniques with increasingly sophisticated models. In terms of the unit of analysis and data sources, all these articles use parent firm-level secondary and archival data sourcing from large databases, such as Compustat, Osiris, Amadeus, and Japanese Overseas Investments, etc. Virtually, none of previous studies use survey data or attempt to obtain insights from MNE managers from field research. 
Another important element of our analysis is that we assess the geographic focus of empirical articles (102 studies), because it has an important impact on the nature of research findings and conclusions. Table 3 presents the distribution of studies according to their geographic focus. Our analysis clearly shows that the United States (the U.S.) and the U.S. firms are the dominant geographic focus in the publication. There are 60 out of 102 articles using US MNEs dataset (almost 60 percent). Studies of European firms (British, German, Swiss and Spanish MNEs) are in the second position (18 papers-18 percent of the total set). Next are Japanese firms (seven papers-seven percent), other Asia Pacific countries (Hong Kong, Korea, Singapore and India) (six papers-six percent), and Canada (one paper). Out of 102 studies with empirical evidence, there are 92 studies using single country datasets (90 percent), and only ten studies using multi-country datasets (ten percent).

Table 3

The results might have various explanations. First, MNEs from the U.S., Europe, and Japan have been amongst the largest and the most active in international markets for a long time. In contrast, firms from emerging economies have internationalized relatively recently (Jormanainen and Koveshnikov, 2012). Second, firms in advanced economies are subject to rigorous requirements in terms of financial data reporting and disclosures. Data availability in large databases is one of the key factors in this research stream. Consequently, to some extent, the M-P literature has become data-driven rather than theory-driven. Third, academic scholars from the U.S. and Europe are actively engaged in investigating the phenomenon of firms of their countries of origin.

There are some methodological limitations in the existing literature. First, the majority of studies are based on a single country, secondary data sources focusing on large MNEs in advanced economies. Thus, this restricts the ability to reflect upon the state of the phenomenon. Second, the dominant use of secondary archival data and quantitative analysis 
in 100 percent of the empirical sample included in our review is probably another methodological limitation. The use of survey and interview data with MNE managers could be complementary to secondary data and qualitative research methods might provide some useful insights on the topic (Yin, 2003). Third, our review analysis reveals that there is a clear lack of comparative analysis studies, and mixed method research design. For example, articles in which the performance of the U.S. firms is compared with that of Japanese or European firms or vice versa are scarce, except Hall \& Rutherford (2003) to compare the U.S. and Korean firms, and Elango and Sethi (2007) to compare firms from small open economies and large economies with modest trade.

Finally, the strong bias towards evidence obtained from the U.S. context is another methodological limitation of the existing literature. This biased geographic focus is problematic, and the generalization of the findings might be limited. In addition, we compare and analyze the empirical results of articles which use the U.S., Europe, and Japanese firms' datasets. We find that previous studies produce mixed results for firms from the same countries of origin. These differences are probably attributed to internal firm-specific characteristics, external business environments in home and host countries, industries, and sectors. Our findings here are consistent with the meta-analysis study by Kirca et al. (2012), as these scholars emphasize that the context (firm, industry and home country) should be accounted for in the M-P literature.

\section{Suggestions for Future Research}

This section offers directions for future research to clarify the inconsistencies. We hope that we will gain a deeper understanding of the impacts of international activities on firm performance. First, we provide a detailed review of previous meta-analysis, literature review, and conceptual articles, in which findings and suggestions for future research by the article authors are reported in Table 4. Second, we present our theory-driven and empirically 
testable suggestions as we believe that such a practical and solution-oriented approach will be useful for future research. Third, Table 4 can be used to compare and contrast our recommendations with those of previous studies.

\section{Table 4}

We elaborate our suggestions in detail as follows:

\section{Suggestion 1: The Key Determinant of a Firm's Performance is FSAs, Not Multinationality per se: An Integrated Perspective of Internalization Theory and Accounting}

From the perspective of internalization theory, the performance of an MNE is not determined by the degree of multinationality, or other aspects of FDI, but by the basic FSAs of the firm itself (Rugman, 1981; Morck and Yeung, 1991; Rugman and Verbeke, 2008; Verbeke \& Brugman, 2009; Kirca et al., 2011; Nguyen, 2011; Rugman et al., 2011; Matysiak and Bausch, 2012; Lee et al., 2015). The FSAs can be developed by parent firms in home countries and by foreign subsidiaries in host countries (Rugman and Verbeke, 1992, 2001; Rugman et al., 2011; Rugman and Nguyen, 2015a, b). In either case, the potential recombination of FSAs with home and host country CSAs is the nexus of strategy for the MNE (Rugman, 1981; Rugman et al., 2011; Nguyen, 2011; Verbeke, 2013).

Rugman and Verbeke (2008) argue that the basic regression on the M-P relationship is misspecified from the perspectives of internalization theory. Multinationality (M) is really an intermediate variable, not an independent variable. Rugman and Verbeke (2008) maintain that if performance $(\mathrm{P})$ is the dependent variable, the true independent variables are FSAs (Rugman, 1981). Rugman and Verbeke (2008) emphasize that these FSAs should never be used as control variables but as the true independent variables determining the performance 
of an MNE. Our suggestion here is consistent with Rugman (1981), and Rugman and Verbeke (2008).

Furthermore, we extend Verbeke \& Brugman (2009) by integrating internalization theory in the IB literature with the perspective of accounting. The determinants of a firm's performance are the efficient and effective utilization of resources and obligations in the balance sheet to deliver performance in the income statement. In other words, a firm's performance is determined by its managerial capabilities of development, deployment, utilization, combination, and the exploitation of its resource bundles (FSAs). The parent firm's financial performance is the consolidated results from the operations within the home country and its network of foreign subsidiaries.

We recommend future research to examine other components in the balance sheet as measurements for FSAs. These include intangible fixed assets (see our earlier discussion on IAS38-Intangible assets); financing sources of liabilities and owners' equities; the use of an efficient internal capital market within the organization structure of the MNE to overcome external capital market imperfections (Rugman, 1980; Mudambi, 1999; Desai et al., 2004; Aulakh and Mudambi, 2005; Nguyen and Rugman, 2015b); and especially financial management capabilities using survey data (Nguyen \& Rugman, 2015b). They are sources of international competitiveness and drivers of value creation for the MNE. In addition, future research is recommended to examine a firm's effectiveness in utilization and exploitation of combined tangible and intangible assets, and financing sources through their foreign subsidiaries.

\section{Suggestion 2: There is a Reverse Effect of Profitability and Overall Performance on} FSAs.

One fruitful direction for future research is to examine the use of retained earnings to finance reinvestments in the continuous development, creation and generation of FSAs for 
sustainable expansion and growth of the firm. In business reality, if an MNE's operation is profitable, it might pay out dividends (depending on its dividend and financing policies). The firm always retains a proportion of profits, known as retained earnings. This is a type of internal equity financing, i.e. internally generated financing sources within the firm as opposed to externally raised equities on the stock exchanges through share issues (Nguyen \& Rugman, 2015b; Rugman \& Collinson, 2012). This is related to the decision of profit reinvestment (reinvested earnings), i.e. the firm retaining and reinvesting its profits into the existing operations (Rugman \& Collinson, 2012; Nguyen, 2015b; Nguyen \& Rugman, 2015b). Our suggestion is built upon the pecking order theory in the finance literature (Myers and Majluf, 1984). There is information asymmetry between managers (insiders) and investors (outsiders). Managers have more inside information than investors and act in favor of old shareholders. The cost of financing increases with information asymmetries. Thus, there is a "pecking" order in corporate financing, in which internal funds (retained earnings) will always be preferred to debt and equity.

We suggest a number of relevant research questions for future studies: To what extent does the firm use retained earnings to finance reinvestments in $R \& D$, given that there are information asymmetries between firms and capital providers and that debt is poorly suited to R\&D funding (Brown et al., 2013)? How does this reinvestment strategy relate to dividend and financing policies? What is the role of retained earnings as a financing source for foreign subsidiaries of MNEs of advanced economies operating in emerging economies where external financial markets are underdeveloped? What are the effects of financing sources on the performance of the firm? How do financial management capabilities affect the strategy and the performance of the firm?

These broad questions are related to the three most important, inter-related decisions in financial management in the MNE, namely, investment, financing and dividend. However, 
the IB literature focuses mainly on initial FDI investment, such as entry mode choice (greenfields versus acquisitions), ownership types (wholly owned foreign subsidiaries WOFSs versus joint ventures JVs), and location choice (Nguyen, 2013). It should be noted that initial FDI might be subject to change over time, such as adjustments to operating modes (e.g. acquire a JV's partner and convert a JV into a WOFS), additional investments or divestments. However, financing, dividend and profit reinvestment strategies have been largely under-researched in the IB literature despite their important implications for MNE managers and public policy makers (Nguyen, 2013; 2015b).

Our recommendation differs from Verbeke and Brugman (2009) who suggest testing the reverse effect of performance on multinationality due to endogeneity concerns. This methodological issue can be addressed using statistical techniques, such as a two-stage least square (2SLS) regression with an instrumental variable approach (Bowen, 2007). Other alternative approaches dealing with endogeneity include control variables and fixed effects, matching and propensity score models, natural experiments, and regression discontinuity design (for endogeneity in IB research, see Reeb et al., 2012; for econometrics, see Wooldridge, 2009).

In addition, we adopt the perspectives of accounting and financial management to analyze the suggestion of testing the reverse effect of performance on multinationality. A firm might consider different investment options other than multinationality after they take into consideration of dividend and financing requirements (Desai et al., 2007; Rugman \& Collinson, 2012; Nguyen \& Rugman, 2015b). For example, investments in financial assets include marketable securities, bonds, etc. Investments in non-financial assets involve purchases of physical, tangible fixed assets (e.g. properties, plants, and equipments). Other investments are $R \& D$ and innovation activities for development and introduction of new products and services, and/or improved process or new business methods; patented 
technology and other intellectual properties; investments in distribution reach and market coverage, and supply chain networks. Alternative options include cash holdings (Foley et al., 2007; Opler et al., 1999; Pinkowitz et al., 2007; Pinkowitz et al., 2012), and share repurchase/ stock buy-back. Finally, the firm might consider expanding domestic and/or international operations contingent upon the growth potential and business opportunities of domestic and foreign markets.

Taking our analysis altogether, we believe that investigating the reverse effect of profitability and overall performance through the use of retained earnings as an important financing source for the reinvestment in FSAs creation is probably a new promising avenue for future research.

\section{Suggestion 3: Replace the Traditional Measurements of Multinationality by Geographic}

Segment (Regional) Measurements in Accordance with International Accounting Standards in Operating Segment Reporting and Disclosures (IFRS8 and US GAAP FASB131)

The measurements of multinationality $(\mathrm{M})$ research need to be re-thought in terms of the accounting data available. Specifically, the international financial reporting standard IFRS8Operating Segments and the US GAAP FASB 131 Disclosures about Segments of an Enterprise and Related Information provide detailed guidance on segment reporting and disclosure requirements. The IFRS8 standard requires public listed entities to disclose information about operating segments, products and services, the geographic areas in which they operate, and their major customers. Information is based on internal management reports, both in the identification of operating segments and measurement of disclosed segment information. Reportable segments are operating segments or aggregation of operating segments that meet specified criteria of either revenues, or profit/loss, or assets at 
10 percent or more of the combined revenues, or profit/loss or assets (see IFRS8 and US GAAP FASB131 websites).

Most of the world's largest firms now report and disclose their geographic segments of sales and/or assets, and related data according to broad geographic regions, such as Europe, North America and Asia Pacific. This allows the traditional multinationality metrics, namely the ratio of foreign sales/ assets/ employees to total sales/ assets/ employees to be replaced by the ratio of regional sales/ assets/ employees to total sales/ assets/ employees. Rugman and Verbeke (2004) provide thought-provoking evidence that MNEs are regional, not global in nature (Rugman and Verbeke, 2004, 2008; Rugman, 2000, 2005, 2007; Rugman and Sukpanich, 2006; Rugman and Oh, 2011; 2013; Oh and Rugman, 2014). Similarly, the foreign subsidiaries of MNEs operate on an entirely home-region basis (Nguyen, 2014, 2015a).

Qian et al. (2008) argue that regionalization can be an optimal way of dealing with empirical conflicts in the M-P literature. Countries within a given region can be relatively similar, in relation to those across regions, in terms of culture, economic development and psychic distance, which measure accurately the costs and benefits associated with international expansion. The expansion of most MNEs is regional rather than global, that is, globalization implies regional diversification rather than balanced, evenly distributed global diversification (Rugman, 2000, 2005).

Furthermore, Rugman and Verbeke (2004) argue that there are significant differences in geographic international expansion costs, in which the liability of intra-regional expansion (i.e. geographic expansion within a home region) is lower than the liability of inter-regional expansion (i.e. geographic expansion across regions). Qian et al. (2013) emphasize that "the liability of country foreignness (LCF)" and "the liability of regional foreignness (LRF)" are different concepts. In terms of conceptualization and measurements, Rugman and Oh (2013) 
have developed regional scale and scope metrics using regional data, which can be employed to address Verbeke \& Brugman's subtest on DI and DID.

The literature will gain an insight into the relationship between M-P by observing and comparing the performance of firms with different levels of regional diversification (Qian et al., 2008). Overall, we suggest that it will be interesting to research if operations in particular regions are more promising than in others.

Suggestion 4: Focus on a Clear Analysis of the Effects of Home Country Operations on Return on Home Assets (ROHA), and the Effects of International Operations on Return on Foreign Assets (ROFA), instead of Examining the Effects of Multinationality on

\section{Return on Total Assets (ROTA) as in the Current Literature}

The key question in terms of assessing a firm's performance is whether or not foreign operations can achieve similar or excess profits in comparison with domestic or other already existing activities. We suggest that the performance measure, such as the consolidated performance results of return on total assets (ROTA) should be decomposed into return on foreign assets and foreign presence (ROFA), and return on home assets and home presence (ROHA) (Gestrin et al., 1998; Rugman et al., 2008). In other words, it would be more logical to assess the relationship between the degree of multinationality and ROFA, not ROTA as in the extant literature.

It is now possible to calculate return on foreign assets (ROFA) and return on home assets as firms report these types of data. However, this approach has been rarely undertaken in previous empirical M-P studies. The studies by Gestrin et al., (1998), and Rugman et al. (2008) are the first and the only ones which have used the new metric of ROFA to examine the return on foreign assets and foreign presence of MNEs, and differentiate between ROHA, ROFA and ROTA. Rugman and his co-authors use carefully hand-coded data, which are collected from firms' annual reports. 
On the other hand, Fisch and Zschoche (2011a, b) examine the aggregated foreign performance of all foreign subsidiaries of German parent firms in terms of ROS and ROE. They have access to a database collected by the Central Bank of Germany of all FDI by German firms. Such efforts by Gestrin et al. (1998), Rugman et al. (2008), and Fisch and Zschoche (2011a, b) in their empirical studies have shed new light on the M-P phenomenon. Our suggestion here provides a clear and practical empirical solution on how to isolate the effects of international activities on performance from those of the home country activities when it comes to the correct assessment of the impact of $\mathrm{M}$ on $\mathrm{P}$, a point which has been briefly commented by Verbeke and Brugman (2009). Overall, we recommend that future research integrates accounting standards and reporting requirements into IB research to improve the empirical design.

\section{Suggestion 5: Use Alternative Value-Based Performance Measurements}

The value of a firm should be assessed on the basis of its future prospects. Specifically, there is a growing interest in measuring shareholder value as opposed to earnings (Martin and Petty, 2007). The concept of Economic Value Added (EVA) originates with the consulting firm Stern Stewart and Co. (Stewart, 1991). EVA is an estimate of a firm's economic profit, which is the value created in excess of the required return of the firm shareholders. EVA measures the firm's financial performance based on the residual wealth calculated by deducting cost of capital from its operating profit (adjusted for taxes on a cash basis). The formula to calculate EVA is as follows: $\mathrm{EVA}=$ net operating profit after tax (NOPAT) (capital $\mathrm{x}$ cost of capital). Shareholders gain when the return from the capital employed is greater than the cost of capital. In other words, EVA measures real wealth for shareholders and it is subject to less distortion by accounting policies and above all it is computed in absolute values. 
In reality, financial analysts make adjustments to accounting data in calculating EVA as they attempt to assess estimated future cash flows. These adjustments include expenditure on $\mathrm{R} \& \mathrm{D}$ for innovation creation and marketing for brand and corporate reputation generation, as well as on staff training for skill development. This approach may contradict the international accounting standard IAS38, because it is too strict in these aspects and discourages managers from investing in intangible knowledge creation and generation, and the development of managerial capabilities which bring long-term benefits to the firm (Martin and Petty, 2007). However, EVA also has limitations because it focuses on short-term objectives.

Our suggestion to use value-based performance measures is consistent with Bowe et al. (2010). These finance scholars suggest that the dependent variables in future M-P research should be able to capture the strategic contribution of on-going corporate projects and firmwide performance by focusing on corporate cash flows. This would signify that a value-based performance measure, such as cash flow return on investment (CFROI) over an appropriate time horizon, could be among the most suitable measures.

\section{Suggestion 6: Incorporate Finance Factors in the Research Design}

We suggest future studies take into account different types of risks (e.g. country risks, operating risks, financial risks, interest rate risks, foreign exchange risks, credit risks, etc.) in the research design. In addition, it will be interesting to conduct content analysis of firms' annual reports to examine how they manage risks as this type of information can be collected from firms' discussion of risks and risk management strategies. When it comes to performance assessment, future research is recommended to use financial returns, adjusted for risks. Our suggestion is in line with Verbeke and Brugman (2009), and Bowe et al. (2010).

Another direction for future research is to use the financial benchmarking method. Financial benchmarking is defined as the establishment by the collection of data of comparators which 
allow relative levels of performance to be identified (Drury, 2009; Seal et al., 2011). The performance of a firm is benchmarked relative to global peers using the industry financial data (a peer group analysis method). This method comes from the field of management accounting and financial management, and it is widely applicable in enterprise risk management, which helps to manage risks across the enterprise, and in the specific areas of credit, market and operational risks.

The studies by Rugman (1983), Rugman and Nguyen (2014), and Rugman et al. (2016) are among the first few attempts, to use the financial benchmarking method to compare the performance of firms in different countries, and to benchmark the performance of firms with global peers using the industry financial data. To some extent, the financial benchmarking method might address some of the criticisms from finance scholars who find that the risk issues have been largely neglected in the existing M-P literature (Bowe et al., 2010). In addition, this method is a useful tool for a comparative analysis, and thus it can be used to address a lack of comparative studies in the current state of the M-P research.

Furthermore, our recommendation to use the financial benchmarking also advances the traditional method used in previous empirical studies of the 1970s-1980s where a comparative approach is employed in which the relative performance of domestic and multinational firms are examined (Annavarjula and Beldona, 2000). We suggest that with fast changing international business environments and increasingly intense competition worldwide, it is more relevant to compare MNEs' performance with their global peers rather than domestic firms.

\section{Suggestion 7: The Need for Research for Other Countries than the United States Context, and the Requirement of Comparative Studies}

We recommend that future research examine strategies and performance of firms from countries other than the U.S. to overcome the inherent limitations of the existing literature, 
which predominantly reflects the corporate behaviour of the U.S. MNEs, the U.S. institutions and business environments, and the U.S. financial markets. A diversity of research contexts and geographic focus will enhance the generalizability of the findings of the literature.

Future empirical studies are suggested to compare and contrast firms from the U.S., Europe, and Japan, those from advanced and emerging economies; firms and their global peers in a particular industry. The insights of comparative studies will enhance our understanding of the research phenomenon, such as whether or not FSAs and multinationality have similar or different effects on the performance of firms from different countries of origin after controlling for the potential effects of firm characteristics, home and host country factors, time periods of investigation, industries and sectors; what are the plausible theory-driven explanations for such similarities and/or differences. The findings from such comparative analysis will provide important practical implications for MNE managers, and advance our theoretical and empirical academic research. Another solution is to conduct cross-country analysis.

\section{Suggestion 8: Examine the Phenomenon from a Subsidiary-Level Perspective}

The unit of analysis is another important issue. Most M-P studies use the parent firm as the unit of analysis and investigate their hypotheses using parent firm-level data. They cannot control directly for the impacts of the interplay between FSAs and internationalization, and performance at the actual level of analysis, which is the foreign subsidiary. In addition, the M-P literature adopts parent-centric perspectives, in which the headquarters transfer knowledge-based FSAs to foreign subsidiaries. Decisions relating to the exploitation of intangible assets and the development of foreign markets are frequently made in the headquarters. This is in line with "classic" internalization theory (Buckley and Casson, 1976; Hennart, 1982; Rugman, 1981). However, in business reality, MNEs face difficulties in transferring FSAs developed by parent firms in home countries to foreign subsidiaries in host 
countries due to the tacit nature of knowledge and location-boundedness and regionboundedness of FSAs (Rugman and Verbeke, 1992; Rugman \& Sukpanich, 2006; Nguyen, 2015b).

Rugman and Verbeke $(1992,2001,2002)$ emphasize that FSAs can be created by both parent firms and by foreign subsidiaries. Rugman and Verbeke (1992) refer to this line of thinking as "new" internalization theory, which is an extension of "classic" internalization theory. Subsidiary initiatives are instrumental for the development of subsidiary-specific advantages (SSAs), which are a special type of FSAs. Previous literature documents that foreign subsidiaries develop new competencies and capabilities in innovation and organizational management, which enhance efficacy for the entire MNE (Birkinshaw, 2000; Cantwell and Mudambi, 2005). Foreign subsidiaries are the engines which drive the combination of knowledge and resources transferred from parent firms with newly-created knowledge and competencies in innovative ways. The recombination knowledge bundles enable them to operate successfully in host countries and ultimately contribute to the performance of their parent firms (Nguyen and Rugman, 2015a, b).

We suggest that future research examine the M-P phenomenon from a subsidiary-level perspective. Studies into the relationship between subsidiary strategy, subsidiary role, decision making of subsidiary managers, development of subsidiary-specific advantages, subsidiary autonomy, host country environments, and subsidiary performance will deepen our understanding of the strategy and performance of the parent firm. Furthermore, such a bottom-up approach is an alternative solution enabling analysis of the strategy and performance of foreign operations of the MNE, because the parent firm performance is the consolidated results from the operations of home country and foreign subsidiaries.

For example, Nguyen and Rugman (2015b) draw upon the insights of new internalization theory in the IB literature (Rugman and Verbeke, 1992, 2001), and the pecking order theory 
in the finance literature (Myers and Majluf, 1984) to examine the relationship between internal equity financing, subsidiary-level financial management capabilities and decision making, and the performance of multinational subsidiaries. The performance is measured by both financial and non-financial indicators, such as actual performance against budget of sales growth, profit growth, return on capital employed (ROCE) and market share growth. They also integrate international accounting standards in their questionnaire design, and they collect data from a survey with managers of British multinational subsidiaries in six countries in the ASEAN region (Malaysia, Indonesia, the Philippines, Singapore and Thailand). The first finding is that that internal equity financing acts as an FSA to improve subsidiary performance. The second finding is that over 90 percent of financing sources (including capital investment by the parent firms) in the British subsidiaries come from internal funding. The third finding is that subsidiary-level financial management decision-making has a statistically significant positive impact on subsidiary performance.

To investigate the major financing sources of the subsidiary, Nguyen and Rugman (2015) ask ASEAN subsidiary managers of British MNEs how they organize their actual financial arrangements. They find that on average, these subsidiaries rely on capital investments transferred from the parent firm for 56 percent of their total funding; on retained earnings for 29 percent; and on intra-firm borrowing (including from the parent firms) for eight percent. Only seven percent of their funding comes from host-country financial institutions and other foreign financial institutions outside host countries. Of the total sample, they find that 84 percent of subsidiaries are profitable. In other words, these subsidiaries use retained earnings to finance continuous improvement of their existing FSAs and development of new FSAs (after they make dividend, interest and royalty payments to their parent firms). This helps foreign subsidiaries to sustain and to maximize their sales growth and overall performance. These findings provide full support for the pecking order theory and reinforce the importance 
of internal capital markets within the MNE organizational structure in accordance with the predictions of internalization theory (Rugman, 1980; Mudambi, 1999; Aulakh \& Mudambi, 2005; Desai et al., 2004; Aggarwal \& Kyaw, 2008). The study by Nguyen and Rugman (2015b) is among the first to test the inter-relationship between FSAs and performance (through retained earnings), as they adopt an original approach of integrating finance theory and accounting principles into IB research.

Rugman and Nguyen (2015b) contribute to the development of theory by advancing the concept of internal equity financing as an FSA, alongside other traditional FSAs in R\&D, innovation, brand and marketing. It is important to recognize that external financial markets in emerging economies in general, and in the ASEAN region (except Singapore) in particular are underdeveloped due to different types of institutional voids. The credit availability might be deficient, the costs and interests of borrowing are high, the access to external financing opportunities might be challenging. Subsidiary managers make strategic decision to use their own retained earnings, which are important financing sources to finance continuing expansion and growth, and to overcome imperfect external capital markets in the host countries. The reinvestment projects are reviewed, assessed, and approved by the headquarters in the annual budgeting in accordance with the requirement of reinvestment

rates (Nguyen, 2015b). This reflects the development and exploitation of financial management capabilities and decision making of subsidiary managers, as they have leveraged their local knowledge and experience to develop sustainable financial management strategies.

\section{Conclusions}

We provide a comprehensive and critical analysis of the multinationality (M) and performance $(\mathrm{P})$ literature by adopting a novel and original inter-disciplinary approach to integrate international business (IB), accounting, and finance perspectives. We examine 135 
articles in 39 leading journals and classic books. We find that the majority of previous studies focus on investigating the effects of multinationality on a firm's performance rather than examining the effects of a firm's internal resources and external environment factors. We review the theoretical foundations, concepts and measurements of $\mathrm{M}, \mathrm{P}$ and the findings on M-P relationships. We identify six key inconsistencies, which cause ambiguity in the current literature. We offer plausible explanations, which include a wide range of theoretical perspectives, inconsistencies in conceptualization and measurements, an omission of riskreturn trade-off, a lack of diversity in geographic focus and research context (the literature is distorted by the dominating use of the U.S. firms' datasets), and a deficiency of comparative studies.

We make eight recommendations for future research directions. Specifically, we suggest that the M-P literature will be more theoretically compelling and empirically robust when IB, finance theories and accounting standards are integrated in future IB research design. From the perspective of internalization theory, the key determinants of a successful IB strategy and thus the performance of an MNE are the basic FSAs relative to rivals, and the effectiveness and efficiency in deploying and augmenting these FSAs across borders, not multinationality per se (Rugman and Verbeke, 2008; Verbeke and Brugman, 2009; Nguyen, 2011; Verbeke, 2013). From the accounting perspective, a firm's performance as reported in the income statement is determined by the efficient and effective deployment, utilization and exploitation of resources and obligations in the balance sheet. Furthermore, we suggest that there is an inter-relationship between FSAs and performance, i.e. FSAs determine performance, which in turn a proportion of profits are then retained in the form of retained earnings and are used to finance reinvestment in the continuous development, generation, and creation of FSAs. This important message differentiates our suggestions from the current literature. 
In addition, we recommend that the traditional multinationality measurements need to be rethought as firms have long implemented the international accounting standard on operating segments reporting and disclosures, especially their geographic operating segments (IFRS8 and US GAAP FASB131). The performance assessment needs to isolate the effects of international activities on return on foreign assets (ROFA) from the effects of home activities on return on home assets (ROHA). We suggest that future research incorporate financespecific factors and risk issues, and use value-based performance measures as it is important to take into consideration the cost of capital of both debt and equity financing. We recommend that future studies move beyond the context and dataset of U.S. firms so that the generalizability of the findings can be improved. Comparative studies which compare and contrast strategies and performance of firms from different countries and/or regions are particularly needed. It is suggested that future research examine this phenomenon from a subsidiary-level perspective. We hope that all these efforts will deepen our understanding of the M-P phenomenon.

Acknowledgements: We would like to thank Professor Joachim Wolf and two anonymous reviewers for their helpful comments and suggestions, which significantly improved this paper. 


\section{REFERENCES}

Aggarwal, R., \& Kyaw, N.A. (2008). Internal capital networks as a source of MNC competitive advantage: Evidence from foreign subsidiary capital structure decisions. Research in International Business and Finance, 22(3), 409-439.

Aggarwal, R., Berrill, J., Hutson, E., \& Kearney, C. (2011). What is a multinational corporation? Classifying the degree of firm-level multinationality. International Business Review, 20, 557-577.

Agmon, T. 2006. Bringing financial economics into international business research: Taking advantage of a paradigm change. Journal of International Business Studies, 37(5): 575-577.

Al-Obaidan, A.M., \& Scully, G.W. (1995). The theory and measurement of the net benefits of multinationality: The case of international petroleum industry. Applied Economics, 27, 231-238.

Allen, L., \& Pantzalis, C. (1996). Valuation of the operating flexibility of multinational corporations. Journal of International Business Studies, 27(4), 633-653.

Annavarjula, M.G., \& Beldona, S. (2000). Multinationality-performance relationship: A review and reconceptualization. The International Journal of Organizational Analysis, 8, 48-67.

Annavarjula, M.G., Beldona, S., \& Sadrieh, F. (2005). Corporate performance implications of multinationality: The role of firm-specific moderators. Journal of Transnational Management, 10(4), $5-27$.

Aulakh, P.S., \& Mudambi, R. 2005. Financial resource flows in multinational enterprises: The role of external capital markets. Management International Review, 45(3), 307-325.

Bae, S.C. \& Jain, V. (2003). The effects of R\&D and international expansion on the performance of US industrial firms. Corporate Finance Review, 8(1), 28-39.

Bae, S.C., Park, B. \& Wang, X. (2008). Multinationality, R\&D intensity, and firm performance: Evidence from US manufacturing firms. Multinational Business Review, 16(1), 53-77.

Barney, J.B. (1991). Firm resources and sustained competitive advantage. Journal of Management, 17(1), 99-120.

Baum, J.A. and Shipilov, V. 2006. Ecological approaches to organizations. In S.R. Clegg, C. Hardy, T. Lawrence and W. Nord (Eds.). Handbook of Organization Studies (pp. 55-110). Thousand Oaks, C.A: Sage.

Bausch, A. \& Krist, M. (2007). The effect of context-related moderators on the internationalizationperformance relationship: Evidence from meta-analysis. Management International Review, 47(3), 319-347.

Benvigvati, A.M. (1987). Domestic profit advantages of multinational firms. Journal of Business, 60, 449-461.

Birkinshaw, J.M. (1996). How multinational subsidiary mandates are gained and lost. Journal of International Business Studies, 27(3), 467-496.

Birkinshaw, J.M. (1997). Entrepreneurship in multinational corporations: The characteristics of subsidiary initiatives. Strategic Management Journal, 18(3), 207-229. 
Birkinshaw, J.M. (1999). The determinants and consequences of subsidiary initiative in multinational corporations. Entrepreneurship Theory and Practice, 24(1), 9-36.

Birkinshaw, J.M. (2000). Entrepreneurship in the global firm. London: Sage.

Birkinshaw, J. M., \& Hood. (1998). Multinational subsidiary evolution: Capability and charter change in foreign owned subsidiary companies. Academy of Management Review, 23(4), 773-795.

Boddewyn, J.J. (1988). Political aspects of MNE theory. Journal of International Business Studies, $19,341-363$.

Booth, L., Aivazian, V., Demirguc-Kunt, A., \& Maksimovic, V. (2001). Capital structure in developing countries. Journal of Finance, 56, 87-130.

Bowen, H. P. (2007). The empirics of multinationality and performance. In A.M. Rugman (ed), Research in Global Strategic Management (Vol. 13): Regional Aspects of Multinationality and Performance (pp. 113-142). Oxford, UK: Emerald.

Bowe, M., Filatotchev, I., \& Marshall, A. (2010). Integrating contemporary finance and international business research. International Business Review, 19(5), 435-445.

Brock, D.M., \& Yaffe, T. (2008). International diversification and performance: The mediating role of implementation. International Business Review, 17, 600-615.

Brown, J.R., Martinsson, G. \& Petersen, B.C. 2013. Law, stock markets, and innovation. Journal of Finance, 68(4), 1517-1549.

Buckley, P., \& Casson, M., (1976). The Future of Multinational Enterprise. Basingstoke and London: Macmillan.

Buehner, R. (1987). Assessing international diversification of West German corporations. Strategic Management Journal, 8(1), 25-37.

Cantwell, J., \& Mudambi, R. (2005). MNE competence-creating subsidiaries. Strategic Management Journal, 26, 11-09-1128.

Cardinal, L.B., Miller, C.C., \& Palich, L.E. (2011). Breaking the cycle of iteration: Forensic failures of international diversification and firm performance research. Global Strategy Journal, 1, 175-186.

Capar, N., \& Kotabe, M. (2003). The relationship between international diversification and performance in service firms. Journal of International Business Studies, 34, 345-355.

Casson, M. (1999). The organization and evolution of the multinational enterprise: An information cost approach. Management International Review, 39, 77-121.

Caves, R.E. (1996). Multinational Enterprises and Economic Analysis. $2^{\text {nd }}$ Edition. Cambridge: Cambridge University Press.

Chandler, A. (1962). Strategy and Structure: Chapters in the History of the American Industrial Enterprise. Cambridge, MA: MIT Press.

Chang, S.C., \& Wang, C.F. (2007). The effect of product diversification strategies on the relationship between international diversification and firm performance. Journal of World Business, 42(1), 969-79. 
Chiang, Y.C., \& Yu, T.H. (2005). The relationship between multinationality and the performance of Taiwan firms. Journal of American Academy of Business, 6(1), 130-134.

Christophe, S.E. (1997). Hysteresis and the value of the US multinational corporation. Journal of Business, 70, 435-462.

Christophe, S.E, \& Lee, H. (2005). What matters about internationalization: A market-based assessment. Journal of Business Research, 58, 636-643.

Click, R., \& Harrison, P. (2002). Does multinationality matter? Evidence of value destruction in US multinational corporations. Paper presented at the Academy of International Business annual meeting, Puerto Rico.

Collins, J.M. (1990). A market performance comparison of U.S. firms active in domestic, developed and developing countries. Journal of International Business Studies, 21, 271-287.

Contractor, F.J. (2007). The evolutionary or multi-stage theory of internationalization and its relationship to the regionalization for a company. In A.M. Rugman (ed). Research in Global Strategic Management (Vol. 13): Regional Aspects of Multinationality and Performance (pp11-29). Oxford, UK: Emerald.

Contractor, F.J. (2012). Why do multinational firms exist? A theory note about the effect of multinational expansion on performance and recent methodological critiques. Global Strategy Journal, 2(4), 318-331.

Contractor, F.J., Kundu, S.K., \& Hsu, C.C. (2003). A three-stage theory of international expansion: The link between multinationality and performance in the service sector. Journal of International Business Studies, 34, 5-18.

Contractor, F.J., Kumar, V., \& Kundu, S.K. (2007). Nature of the relationship between international expansion and performance: The case of emerging market firms. Journal of World Business, 42(4), 401-417.

Daniels, J.D., \& Bracker, J. (1989). Profit performance: Do foreign operations make a difference? Management International Review, 29(1), 46-56.

Dariau, V.J., Reger, R., \& Pafarrer, M.D. (2007). A content analysis of the content analysis literature in organization studies: Research themes, data sources, and methodological refinements. Organizational Research Methods, 10(5), 5-34.

Dastidar, P. (2009). International corporate diversification and firm performance: Does firm selfselection matter? Journal of International Business Studies, 40, 71-85.

Denis, D., Denis, D., \& Yost, K. (2002). Global diversification industrial diversification and firm value. Journal of Finance, LVII(5), 1951-1979.

de Jong, G., \& van Houten, J. (2014). The impact of MNE cultural diversity on the internationalization performance relationship: Theory and evidence from European multinational enterprises. International Business Review, 23, 313-326.

Delios, A., \& Beamish, P. W. (1999). Geographic scope, product diversification and the corporate performance of Japanese firms. Strategic Management Journal, 20(8), 711-727. 
Desai, M.A., Foley, C.F., \& Hines, J.J.R. (2004). A multinational perspective on capital structure choice and internal capital markets. Journal of Finance, 59(6), 2451-2487.

Desai, M. A., Foley, C. F., \& Hines, J. R. (2007). Dividend policy inside the multinational firm. Financial Management, 36(1), 5-26.

Dess, G., Gupta, A., Hennart, J.F., \& Hill, C. (1995). Conducting and integrating strategy research at the international, corporate and business levels: Issues and directions. Journal of Management, 21(3), $357-393$.

Doukas, J.A., \& Kan, O.B. (2006). Does global diversification destroy firm value? Journal of International Business Studies, 37, 352-371.

Dunning, J.H. (1985). The United Kingdom. In Dunning, J.H. (ed.), Multinational Enterprises, Economic Structure and International Competitiveness. Chichester: John Wiley.

Dunning, J.H. (1998). Location and the multinational enterprise: A neglected factor? Journal of International Business Studies, 29, 45-66.

Drury, C. 2009. Management Accounting for Business, $4^{\text {th }}$ edition. Australia: Cengage Learning.

Eckert, S., Dittfeld, M., Muche, T., \& Raesser, S. (2010). Does multinationality lead to value enhancement? An empirical examination of publicly listed corporations from Germany. International Business Review, 19, 562-574.

Eden, L., \& Miller, S. (2001). Opening the black box: Multinationals and the costs of doing business abroad. Academy of Management Best Paper Proceedings.

Elango, B. (2000). An exploratory study into the linkages between corporate resources and the extent and form of internationalization of US firms. American Business Review, 18(2), 12-26.

Elango, B., \& Sethi, S.P. (2007). An exploration of the relationship between country of origin (COE) and the internationalization-performance paradigm. Management International Review, 47(3), 369392.

Errunza, V. R., \& Senbet, L. W. (1981). The effects of international operations on the market value of the firm: Theory and evidence. Journal of Finance, 36(2), 401-417.

Ferraris, S.P., Sen, N., Nguyen, T.A.T. (2010). Firm value and the diversification choice: International evidence from global and industrial diversification. Applied Economics Letters, 17, 1027-1031.

Fisch, J.H., \& Zschoche, M. (2011a). The effects of liabilities of foreignness, economies of scale, and multinationality on firm performance: An information cost view. Schmalenbach Business Review, 3(11), 51-68.

Fisch, J.H., \& Zschoche, M. (2011b). Do firms benefit from multinationality through production shifting? Journal of International Management, 17, 143-149.

Foley, C. F., Hartzell, J., Titman, S., \& Twite, G. Why do firms hold so much cash? A tax-based explanation. Journal of Financial Economics, 86(3), 579-607.

Gande, A., Schenzler, C., \& Senbet, L.W. (2009). Valuation effects of global diversification. Journal of International Business Studies, 40, 1515-1532. 
Gao, G.Y., Pan, Y., Lu, J., \& Tao, Z. 2008. Performance of multinational subsidiaries: Influences of cumulative experience. Management International Review, 48(6): 749-768.

Gedajlovic, E.R., \& Shapiro, D.M. (1998). Management and ownership effects: Evidence from five countries. Strategic Management Journal, 19(6), 533-553.

Geringer, M.J., Beamish, P.W., \& da Costa, R.C. (1989). Diversification strategy and internationalization: Implications for MNE performance. Strategic Management Journal, 10, 109-119.

Geringer, J.M., Tallman, S., \& Olsen, D.M. (2000). Product and international diversification among Japanese multinational firms. Strategic Management Journal, 21, 51-80.

Gestrin, M., Knight, R., \& Rugman, A.M. (1998). The Templeton Global Performance Index. The Oxford Executive Research Briefings: Templeton College.

Glaum, M., \& Oesterle, M-J. (2007). Forty years of research on internationalization and firm performance: More questions than answers? Management International Review, 47(3), 307-317, Focused Issue.

Goerzen, A., \& Beamish, P.W. (2003). Geographic scope and multinational enterprise performance. Strategic Management Journal, 24(13), 1289-306.

Gomez-Meija, L.R., \& Palich, L.E. (1997). Cultural diversity and the performance of multinational firms. Journal of International Business Studies, 28(2), 309-334.

Gomes, L., \& Ramaswany, K. (1999). An empirical examination of the form of the relationship between multinationality and performance. Journal of International Business Studies, 30, 173-188.

Goossens, E., \& Doom, J. 2013. Biggest Solar Collapse in China Imperils \$1.28 Billiony. Bloomberg.

Grant, R.M. (1987). Multinationality and performance among British manufacturing companies. Journal of International Business Studies, 18(3), 79-89.

Grant, R.M., Jammine, A.P., \& Thomas, H. (1988). Diversity, diversification and profitability among British manufacturing firms, 1972-1984. Academy of Management Journal, 31, 771-801.

Hall, J.LE., \& Rutherford, Jr. M.W. (2003). A comparative study of US and Korean firms: Changes in diversification and performance. International Journal of Commerce and Management, 13(1), 11-41.

Henderson, A.D. (1999) Firm strategy and age dependence: A contingent view of the liabilities of newness, adolescence, and obsolescence. Administrative Science Quarterly, 44, 281-314.

Hennart, J.F. (1982). A theory of multinational enterprise. Ann Arbor, University of Michigan Press.

Hennart, J. F. (2007). The theoretical rationale for a multinationality-performance relationship. Management International Review, 47(3), 423-452.

Hennart, J. F. (2011). A theoretical assessment of the empirical literature on the impact of multinationality on performance. Global Strategy Journal, 1(1-2), 135 - 151

Hitt, M.A., Hoskisson, R.E., \& Kim, H. (1997). International diversification: Effects on innovation and firm performance in product-diversified firms. Academy of Management Journal, 40(4), 767-798. 
Hitt, M.A., Bierman, L., Uhlenbruck, K., \& Simizu, K. (2006). The importance of resources in the internationalization of professional service firms: The good, the bad, and the ugly. Academy of Management Journal, 49, 1137-1157.

Hitt, M. A., Tihanyi, L., Miller, T., \& Connelly, B. (2006). International diversification: Antecedents, outcomes, and moderators. Journal of Management, 32, 831-867.

Hofstede, G. (1983). The cultural relativity of organizational practices and theories. Journal of International Business Studies, 14(2), 75-89.

Hofstede, G. (2006). What did GLOBE really measure? Researchers' minds versus respondents' minds. Journal of International Business Studies, 37(6), 882-896.

Horst, T. (1972). Firm and industry determinants of the decision to invest abroad: An empirical study. The Review of Economics and Statistics, 54(3), 258-266.

House, R.J., Hanges, P.J., Javidan, M., Dorfman, P.W., \& Gupta, V. (2004). Culture, Leadership and Organizations: The GLOBE study of 62 societies. Thousand Oaks, CA: Sage.

Hughes, J.S., Logue, D.E., \& Sweeney, R.J. (1975). Corporate international diversification and market assigned measures of risk and diversification. Journal of Financial and Quantitative Analysis, Nov., 627-637.

Hult, G. T. M. (2011). Commentaries: A strategic focus on multinationality and firm performance. Global Strategy Journal, 1, 171-174.

Hult, G. T. M., Ketchen, D. J., Griffith, D. A., Chabowski, B. R., Hamman, M. K., Dykes, B. J., Pollitte, W. A., \& Cavusgil, S T. (2008). An assessment of the measurement of performance in international business research. Journal of International Business Studies, 39, 1060-1080.

Hutzschenreuter, T., \& Voll, J. C. (2008). Performance effects of "added cultural distance" in the path of international expansion: the case of German multinational enterprises. Journal of International Business Studies, 39(1), 53-70.

Hutzschenreuter, T., Voll, J.C., \& Verbeke, A. (2011). The impact of added cultural distance and cultural diversity on international expansion patterns: A Penrosean perspective. Journal of Management Studies, 48(2), pp 305-329.

Hymer, S. H. (1960). Ph.D Thesis, MIT. The international operations of national firms: A study of direct foreign investment. (Subsequently published by Cambridge, Mass.: MIT Press under the same title in 1976).

IFRS8-Operating Segments, www.ifrs.org/IFRSs/Documents/IFRS8en.pdf [accessed Mar 14, 2015].

IAS38-Intangible Assets, www.ifrs.org/IFRSs/IFRS-technical-summaries/.../IAS38-English.pdf [accessed Mar 14, 2015].

Johanson, J., \& Vahlne, J.-E. (1977). The internationalization process of the firm: A model of knowledge development and increasing foreign market commitments. Journal of International Business Studies, 8(1), 23-32. 
Jormanainen, I., \& Koveshnikov, A. (2012). International activities of emerging market firms: A critical assessment of research in top international management journals. Management International Review, 52(5), 691-725.

Jung, Y. (1991). Multinationality and profitability. Journal of Business Research, 23, 179-187.

Jung, J.C., \& Bansal, B. (2009). How performance affects internationalization. Management International Review, 49(6), 709-732.

Kim, S.S. (2009). A study on the relationship between multinationality and performance among Korean firms. Journal of Korea Trade, 14(1), 67-90.

Kim, W. S., \& Lyn, E. O. (1986), Excess market value, the multinational corporation, and Tobin qRatio. Journal of International Business Studies, 17(1), 119-125.

Kim, C.W., \& Mauborgne, R.A. (1993). Making global strategies work. Sloan Management Review, 34(3), 11-27.

Kim, W.C., Hwang, P., \& Burgers, W.P. (1989). Global diversification strategy and corporate profit performance. Strategic Management Journal, 10 (January), 45-57.

Kim, W.C., Hwang, P., \& Burgers, W.P. (1993). Multinationals' diversification and risk-return tradeoff. Strategic Management Journal, 14, 275-286.

Kim, H., Hoskisson, R.E., \& Wan, W.P. (2004). Power dependence, diversification strategy, and performance in keiretsu member firms. Strategic Management Journal, 25, 613-636.

Kim, Y.S., \& Mathur, I. (2008). The impact of geographic diversification on firm performance. International Review of Financial Analysis, 17, 747-766.

Kirca, A.H., Hult, T.M., Roth, K., Cavusgil, S.T., Perry, M.Z., Akdeniz, M.B., Deligonul, S.Z., Mena, Z.A., Pollitte, W.A., Hoppner, J.J., Miller, J.C., \& White, R.C. (2011). Firm specific assets, multinationality, and financial performance: A meta-analytic review and theoretical integration. Academy of Management Journal, 54(1), 47-72.

Kirca, A.H., Hult, T.M., Deligonul, S.Z.. Perry, M.Z.. \& Cavusgil, S.T. (2012). A multilevel examination of the drivers of firm multinationality: A meta analysis. Journal of Management, 38(2), $502-530$.

Kirca, A.H., Roth, K., Hult, T.M., \& Cavusgil, S.T. (2012). The role of context in the multinationality-performance relationship: A meta-analytic review. Global Strategy Journal, 2(2), 108-121.

Kobrin, S.J. (1991). An empirical analysis of the determinants of global integration. Strategic Management Journal, 12, 17-31.

Kogut, B., \& Singh, H. (1988). The effect of country culture on the choice of entry mode. Journal of International Business Studies, 19(3), 411-423.

Kotabe, M., Srinivasan, S.S., \& Aulakh, P.S. (2002). Multinationality and firm performance: The moderating role of R\&D and marketing capabilities. Journal of International Business Studies, 33(1), 79-97. 
Kumar, M.S. (1984). Growth, Acquisition and Investment: An Analysis of the Growth of Industrial Firms and Their Overseas Activities. Cambridge and New York: Cambridge University Press.

Lee, S., Kim, M., \& Davidson III, W. N. (2015). Value relevance of multinationality: Evidence from Korean firms. Journal of International Financial Management \& Accounting, 26(2), 111-149.

Li, L. (2005). Is regional strategy more effective than global strategy in the US service industries? Management International Review, 45(S1), 37-57.

Li, L. (2007). Multinationality and performance: A synthetic review and research agenda. International Journal of Management Reviews, 9 (2), 117-139.

Li, L., \& Qian, G. (2005). Dimensions of international diversification: the joint effects on firm performance. Journal of Global Marketing, 18(3/4), 7-35.

Lin, T., Er, J.P., \& Winston, K.C.C. (2005). International diversification and performance: Evidence from Singapore. Asia Pacific Journal of Management, 22, 65-88.

Lu, J.W., \& Beamish, P. (2004). International diversification and firm performance: the S-curve hypothesis. Academy of Management Journal, 47(4), 598-609.

Martin, J.D., \& Petty, J.W. (2000). Value Based Management. Harvard: Harvard Business School Press.

Marthur, I., Singh, M., \& Gleason, K.C. (2001). The evidence from Canadian firms on multinational diversification and performance. The Quarterly Review of Economics and Finance, 41(4), 561-578.

Matysiak, L., \& Bausch, A. (2012). Antecedents of MNE performance: Blinded by the obvious in 35 years of literature. Multinational Business Review, 20(2), 178-211.

McDonald, F., Warhurst, S., \& Allen, M. (2008). Autonomy, embeddedness and the performance of foreign owned subsidiaries. Multinational Business Review, 16(3), 73-92.

McSweeney, B. (2002). Hofstede's model of national cultural differences and their consequences: A triumph of faith - a failure of analysis. Human Relations, 55(1), 89-118.

Michel, A., \& Shaked, I. (1986). Multinational corporations versus domestic corporations: Financial performance and characteristics. Journal of International Business Studies, 18(3), 89-100.

Morales, A., \& Martin, C. 2013. Suntech Defaults on \$541 Million Bond: A First for China. Bloomberg.

Morck, R., \& Yeung, B (1991). Why investors value multinationality? The Journal of Business, 64(2), $165-187$.

Morck, R., \& Yeung, B. (2009). Metrics for international business research. In A.M. Rugman (Ed), The Oxford Handbook of International Business, $2^{\text {nd }}$ Edition, (pp 798-815). Oxford: Oxford University Press.

Mudambi, R. (1999). MNE internal capital markets and subsidiary strategic independence. International Business Review, 8, 197-211. 
Myers, S. C., \& Majluf, N. S. 1984. Corporate financing and investment decisions when firms have information that investors do not have. Journal of Financial Economics, 13: 187-222.

Nguyen, Q.T.K. (2011). The empirical literature on multinational enterprises, subsidiaries and performance. Multinational Business Review, 19(1), 47-64.

Nguyen, Q.T.K. (2013). Can British multinational enterprises finance economic development in South East Asia? Multinational Business Review, 21(2), 122-147.

Nguyen, Q.T.K. (2014). The regional strategies of British multinational subsidiaries in South East Asia. British Journal of Management, 25, 60-76.

Nguyen, Q.T.K. (2015a). The subsidiaries of multinational enterprises operate regionally, not globally. Multinational Business Review, 23(4), 328-354.

Nguyen, Q.T.K. (2015b). The determinants of reinvested earnings of multinational subsidiaries in emerging economies. In Heinz Tueselmann, Buzdugan, S. Cao, Q., Freund, D. \& Golesorkhi, S. (eds), Impact of International Business: Challenges and Solutions for Policy and Practice (pp 43-61). London: Palgrave Macmillan.

Nguyen, Q.T.K., \& Rugman, A.M. (2015a). Multinational subsidiary sales and performance in South East Asia. International Business Review, 24, 115-123.

Nguyen, Q.T.K., \& Rugman, A.M. (2015b). Internal equity financing and the performance of multinational subsidiaries in emerging economies. Journal of International Business Studies,46(4), 468-490.

Ningbo Veken Elite Group (2012). Annual report (2012). Access via China Stock Market http://www.china-stock.org/ningbo-veken-elite-group-co-ltd/ [accessed July 22, 2015].

OECD (2014) Base Erosion and Profit Shifting Initiative. http://www.oecd.org/ctp/beps.htm [Accessed December 17, 2015].

Oesterle, M. J., \& Wolf, J. (2011). Fifty years of management international review and IB/ IM research: An inventory and some suggestions for the field's development. Management International Review, 51(6), 735-754.

Oesterle, M-J., \& Richta, H.N. (2013). Internationalisation and firm performance: state of empirical research efforts and need for improved approaches. European Journal of International Management, 7(2), 204-224.

Oh, C.H., \& Contractor, F. (2014). A regional perspective on multinational expansion strategies: Reconsidering the three-stage paradigm. British Journal of Management, 25(Supplement 1), 42-59.

Oh, C.H., \& Rugman, A.M. (2014). The dynamics of regional and global multinationals, 1999-2008. Multinational Business Review, 22(2), 108-117

Opler, T., Pinkowitz, L., Stulz, R., \& Williamson, R. (1999). The determinants and implications of cash holdings. Journal of Financial Economics, 52, 3-46.

Oxelheim, L., Randoy, T., \& Stonehill, A. (2001). On the treatment of finance-specific factors within the OLI paradigm. International Business Review, 10(4), 381-398. 
Oxelheim, L., Randoy, T., \& Stonehill, A. (2012). What can international finance add to international strategy. In Alain Verbeke and Hemant Merchant (Eds) Handbook of Research on International Strategic Management, pp 238-256. Cheltenham, UK: Edward Elgar.

Palich, L., Cardinal, L., \& Miller, C. (2000). Curvilinearity in the diversification-performance linkage: An examination of over three decades of research. Strategic Management Journal, 21, 155-174.

Pantzalis, C. (2001). Does location matter? An empirical analysis of geographic scope and MNC market valuation. Journal of International Business Studies, 32, 133-155.

Pattnaik, C., \& Elango, B. (2009). The impact of firm resources on the internationalization and performance relationship: A study of Indian manufacturing firms. Multinational Business Review, 17(2), 69-87.

Penrose, E. (1959). The Theory of the Growth of the Firm. New York: John Wiley and Sons.

Pinkowitz, L., Williamson, R., \& Stulz, R.M. (2007). Cash holdings, dividend policy and corporate governance: A cross-country analysis. Journal of Applied Corporate Finance, 19(1), 81-87.

Pinkowitz, L., Stulz, R. M., \& Williamson, R. (2012). Multinationals and the high cash holdings puzzle. Working paper. The National Bureau of Economic Research. Available at http://www.nber.org/papers/w18120 [Access December 31, 2015].

Porter, M.E. (1990). The Competitive Advantage of Nations. New York: Free Press.

Powell, K.S. (2013). From M-P to MA-P: Multinationality alignment and performance. Journal of International Business Studies, 45, 211-226

Qian, G. (1997). Assessing product-market diversification of U.S. firms. Management International Review, 37(2), 127-149.

Qian, G. (1998). Determinants of profit performance for the largest US firms 1981-1992. Multinational Business Review, Fall, 44-51.

Qian, G. (2002). Multinationality, product diversification, and profitability of US emerging and medium-sized enterprises. Journal of Business Venturing, 17(6), 611-634.

Qian, G., \& Li, J. (2002). Multinationality, global market diversification and profitability among the largest US firms. Journal of Business Research, 55(4), 325-335.

Qian, G., Li, L., Li, J., \& Qian, Z. (2008). Regional diversification and firm performance. Journal of International Business Studies, 39, 197-214.

Qian,G., Li, L., \& Rugman, A.M. (2013). Liability of country foreignness and liability of regional foreignness: Their effects on geographic diversification and firm performance. Journal of International Business Studies, 44, 635-647.

Ramaswamy, K. (1992). Multinationality and performance: A synthesis and redirection. Advances in International Competitive Management, 7, 241-267.

Ramaswamy, K. (1995). Multinationality, configuration, and performance: A study of MNEs in the US drug and pharmaceutical industry. Journal of International Management, 1, 231-253. 
Ramaswamy, K., Kroeck, K.G., \& Renforth, W. (1996). Measuring the degree of internationalization of a firm: A comment. Journal of International Business Studies, 27(1), 167-177.

Ramirez-Aleson, M., \& Espitia-Escuer, M.A. (2001). The effect of international diversification on performance. Management International Review, 41, 291-315.

Reeb, D.M, Kwok, C.C., \& Baek, Y.H. (1998). Systematic risk of the multinational corporation. Journal of International Business Studies, 29, 263-279.

Reeb, D., Sakakibara, M., \& Mahmood, I.P. (2012). From the editors: Endogeneity in international business research. Journal of International Business Studies, 43(3), 211-218.

Riahi-Belkaoui, A. (1998). The effects of the degree of internationalization on firm performance. International Business Review, 7, 315-321.

Ross, S.A. (1973). The economic theory of agency: The principal's problem. American Economic Review, 63(2), 134-139.

Roth, K., \& Morrison, A.J. 1992. Implementing global strategy: Characteristics of global subsidiary mandates. Journal of International Business Strategy, 23(4), 715-735.

Ruigrok, W., \& Wagner, H (2003). Internationalization and performance: An organizational learning perspective. Management International Review, 43(1), 63-83.

Ruigrok, W., Amann, W., \& Wagner, H. (2007). The internationalization-performance relationship at Swiss firms: A test of the S-shape and extreme degrees of internationalization. Management International Review, 47, 349-368.

Rugman, A.M. (1976). Risk reduction by international diversification. Journal of International Business Studies, 7, 75-80.

Rugman, A.M. (1980). Internalization theory and corporate international finance. California Management Review, 23(2): 73-79.

Rugman, A.M. (1981). Inside the Multinationals: The Economics of Internal Markets. New York: Columbia University Press.

Rugman, A. M. (1983). The comparative performance of U.S. and European multinational enterprises, 1970-1979. Management International Review, 23(2), 4-14.

Rugman, A.M. (2000). The End of Globalization. London: Random House.

Rugman, A.M. (2005). The Regional Multinationals: MNEs and "Global" Strategic Management. Cambridge and New York: Cambridge University Press.

Rugman, A.M. (Ed.) (2007). Research in Global Strategic Management (Vol. 13): Regional Aspects of Multinationality and Performance. Oxford: Elsevier.

Rugman, A.M. (2013). Multinationals and transfer pricing summary. Henley Business School Seminar, University of Reading.

Rugman, A.M. \& Collinson, S. (2012). International Business, 6th Edition. Harlow, Essex: Pearson. 
Rugman, A. M., \& Oh, C. H. (2010). Does the regional nature of multinationals affect the multinationality and performance relationship? International Business Review, 19 (5), 479-488

Rugman, A.M., \& Oh, C.H. (2011). Methodological issues in the measurement of multinationality of U.S. firms. Multinational Business Review, 19(3), 202-212.

Rugman, A.M., \& Oh, C.H. (2013). Why the home region matters: Location and regional multinationals. British Journal of Management, 24(4), 463-479.

Rugman, A.M., \& Nguyen, Q.T.K. (2014). Modern international business theory and emerging economy multinational companies. In A. Cuervo-Cazurra \& R. Ramamurti (eds.) Understanding Multinationals from Emerging Markets (pp 53-80). Cambridge, UK: Cambridge University Press.

Rugman, A.M., \& Sukpanich, N. (2006). Firm specific advantages, intra-regional sales and performance of multinational enterprises. The International Trade Journal, 20(3), 355-382.

Rugman, A.M., \& Verbeke, A. (1992). A note on the transnational solution and the transaction cost theory of multinational strategic management. Journal of International Business Studies, 23(4), 761772 .

Rugman, A.M., \& Verbeke, A. (2001). Subsidiary-specific advantages in multinational enterprises. Strategic Management Journal, 22, 237-250.

Rugman A.M., \& Verbeke, A. (2002). Edith Penrose's contribution to the resource-based view of strategic management. Strategic Management Journal, 23(8), 769-780.

Rugman, A.M., \& Verbeke, A. (2004). A perspective on regional and global strategies of multinational enterprises. Journal of International Business Studies, 35(1), 3-18.

Rugman, A.M., \& Verbeke, A. (2008). Internalization theory and its impact on the field of international business. In J.J. Boddewyn (ed.), (Research on Global Strategic Management), Vol. 14, International Business Scholarship: AIB Fellows on the First 50 Years and Beyond, (pp.155-174). Bradford: Emerald Group.

Rugman, A.M., Lecraw, D.L., \& Booth, L.D. (1985). International Business: Firm and Environment. New York: McGraw-Hill.

Rugman, A.M., Nguyen, Q.T.K., \& Wei, Z. (2016). Rethinking the literature on the performance of Chinese multinational enterprises. Management and Organization Review, forthcoming.

Rugman, A.M., Verbeke, A., \& Nguyen, Q.T.K. (2011). Fifty years of international business and beyond. Management International Review, 51(6), 755-786.

Rugman, A.M., Yip, G., \& Jayaratnet, S. (2008). A note on return on foreign assets and foreign presence for UK multinationals. British Journal of Management, 19, 162-170.

Ruigrok, W., \& Wagner, H (2003). Internationalization and performance: An organizational learning perspective. Management International Review, 43(1), 63-83.

Ruigrok, W., Amann, W., \& Wagner, H. (2007). The internationalization-performance relationship at Swiss firms: A test of the S-shape and extreme degrees of internationalization. Management International Review, 47(3), 349-368. 
Ryan, N. (2011). Economic value added versus profit-based measures of performance. ACCA website http://www.acca.co.uk/pubs/ [accessed Nov 10, 2014]

Sambharya, R. B. (1995). The combined effect of international diversification and product diversification strategies on the performance of US-based multinational corporations. Management International Review, 35(3), 197-213.

Seal, W., Garrison, G. H., \& Norren, E. W. (2011). Management Accounting. Berkshire: McGrawHill Education.

Severn, A.K., \& Laurence, M.M. (1974). Direct investment, research intensity, and profitability. Journal of Financial and Quantitative Analysis, 181-190.

Shaked, I. (1986). Are multinational corporations safer? Journal of International Business Studies, Spring, 83-106.

Shenkar, O. (2001). Cultural distance revisited: Towards a more rigorous conceptualization and measurement of cultural differences. Journal of International Business Studies, 32(3), 519-535.

Shiller, R.J. (2000). Irrational Exuberance. Princeton, NJ: Princeton University Press.

Siddharthan, N.S., \& Lall, S. (1982). Recent growth of the largest U.S. multinationals. Oxford Bulletin of Economics and Statistics, 44, 1-13.

Stahl, G.K., \& Tung, R. (2015). Towards a more balanced treatment of culture in international business studies: The need for positive cross-cultural scholarship. Journal of International Business Studies, 46, 391-414

Stopford, J.M., \& Wells, L.T. Jr. (1972). Managing the Multinational Enterprise: Organization of the Firm and Ownership of the Subsidiaries. London, UK: Basic Books.

Suddaby, R., \& Greenwood, R. (2005). Rhetorical strategies of legitimacy. Administrative Science Quarterly, 50(1), 35-67.

Sullivan, D. (1994a). Measuring the degree of internationalization of a firm. Journal of International Business Studies. 25(2), 325-342.

Sullivan, D. (1994b): Threshold of internationalization: Replication, extension, and reinterpretation. Management International Review, 34, 165-186.

Sui-Lee, W. 2013-03-20. UPDATE 2-Solar pain hits China as Suntech unit nears insolvency. Reuters.

Stewart, G.B. III (1991). The Quest for Value. HarperCollins.

Tallman, S., \& Li, J. (1996). Effects of international diversity and product diversity on the performance of multinational firms. Academy of Management Journal, 39, 179-196.

Tallman, S., Geringer, J.M., \& Olsen, D.M. (2004). Contextual moderating effects and the relationship of firm-specific resources, strategy, structure and performance among Japanese multinational enterprises. Management International Review, 44, 107-128.

The UK Parliament, Public Accounts Committee. 2012. Public Accounts Committee, Minutes of Evidence, HC 716. 
http://www.publications.parliament.uk/pa/cm201213/cmselect/cmpubacc/716/121112.htm [accessed March 22, 2016].

Thomas, D.E. (2006). International diversification and firm performance in Mexican firms: A curvilinear relationship. Journal of Business Research, 59, 501-507.

Thomas, D.E., \& Eden, L. (2004). What is the shape of the multinationality-performance relationship? Multinational Business Review, 12(1), 89-110.

Teece, D. (1986). Transaction cost economics and the multinational enterprise: An assessment. Journal of Economics Behaviour and Organization, 7, 21-45.

Teece, D., Pisano, G., \& Shuen, A. (1997). Dynamic capabilities and strategic management. Strategic Management Journal, 18(8), 537-556

Tushman, M., \& Romanelli, E. (1985). Organizational evolution: a metamorphis of convergence and reorientation. In L. Cummings and Staw, B. (eds), Research in Organizational Behavior (pp. 171222). Greenwich: JAI Press.

Tung, R., \& Verbeke, A. (2010). Beyond Hofstede and GLOBE: Improving the quality of crosscultural research. Journal of International Business Studies, 41(8), 1259-1274.

Venkatraman, N., and Ramanujam, V. (1986). Measurement of business performance in strategy research: A comparison of approaches. Academy of Management Review, 11(4), 801-814.

Verbeke, A. (2013). International Business Strategy, Second edition. Cambridge: Cambridge University Press.

Verbeke, A., \& Brugman, P. (2009). Triple testing the quality of multinationality-performance research: An internalization theory perspective. International Business Review, 18, 265-275.

Verbeke, A., \& Forootan, Z.M. (2012). How good are multinationality performance (M-P) empirical studies? Global Strategy Journal, 2(4), 332-344.

Verbeke, A., Li, L., \& Goerzen, A. (2009). Toward more effective research on the multinationalityperformance relationship. Management International Review, 49(2), 1-13.

Vernon, R. (1971). Sovereignty at Bay. London: Longman Group Ltd.

UNCTAD. (2013). World Investment Report. Geneva: United Nations Conference on Trade and Development (UNCTAD).

US GAPP, Financial Accounting Standard Board, FASB131 - Disclosures about Segments of an Enterprise and Related Information http://www.fasb.org/summary/stsum131.shtml [accessed Mar 14, 2015].

Wan, C.C. (1998). International diversification, industrial diversification, and firm performance of Hong Kong MNCs. Asia Pacific Journal of Management, 15, 205-217.

Wang, C.-F. Chen, L-Y. \& Chang, S.-C. (2011). International diversification and the market value of new product introduction. Journal of International Management, 17, pp 333-347. 
Welch, C., Piekkari, R., Plakoyiannaki, E., \& Paavilainen-Maentymaeki, E. (2011). Theorizing from case studies: Towards a pluralist future for international business research. Journal of International Business Studies, 42(5), 740-762.

Wernerfelt, B. (1984). The resource-based view of the firm. Strategic Management Journal, 5(2), $171-180$.

Whited, T.M. (2001). Is it inefficient investment that causes the diversification discounts? Journal of Finance, 56(5), 1667-1691.

Wiersema, M.F., \& Bowen, H.P. (2011). The relationship between international diversification and firm performance: Why it remains a puzzle. Global Strategy Journal, 1, 157-170.

Wooldridge, J.M. (2009). Introductory Econometrics: A Modern Approach. South Western Cengage Learning.

Yang, Y., \& Driffield, N. (2012). Multinationality-performance relationship: A meta-analysis. Management International Review, 52, 23-47.

Yang, Y., Martins, P.S., \& Driffield, N. (2013). Multinational performance and the geography of FDI: Evidence from 46 countries. Management International Review, 53, 763-794.

Yin, R.K. (2003). Case Study Research: Design and Methods. Thousand Oaks: Sage.

Yoshihara, H. (1985). Multinational Growth of Japanese Manufacturing Enterprises in the Post War Era. The proceedings of the Fuji international conference on business history. Tokyo: Tokyo University Press.

Zaheer, S. (1995). Overcoming the liability of foreignness. Academy of Management Journal, 38, 341-363.

Zahra, S.A., Ireland, R.D., \& Hitt, M.A. (2000). International expansion by new venture firms: International diversity, mode of market entry, technological learning and performance. Academy of Management Journal, 43(5), 925-950.

Zaheer, S. (1995). Overcoming the liability of foreignness. Academy of Management Journal, 38(2), 341-363.

Zhou, L., Wu, W.P., \& Luo, X. (2007). Internationalization and the performance of born-global SMEs: The mediating role of social networks. Journal of International Business Studies, 38(4), 673 690. 


\section{Figure 1: Multinationality $(M)$ and performance $(P)$ literature}

Theorizing on the $M-P$ relationship: Multinationality $(M)$ determines Performance $(P)$

(Theories and theoretical foundations: benefits and costs of internationalization in static and dynamic fashions)

\begin{tabular}{|c|c|c|c|}
\hline$\sqrt{ }$ & $\downarrow$ & $\downarrow$ & $\downarrow$ \\
\hline $\begin{array}{l}\text { Internalization } \\
\text { theory; Dunning's } \\
\text { OLI; the resource- } \\
\text { based view of the } \\
\text { firm; Portfolio and } \\
\text { diversification } \\
\text { theory }\end{array}$ & $\begin{array}{l}\text { Liability of } \\
\text { internationalization; } \\
\text { Liability of } \\
\text { foreignness; Agency } \\
\text { theory }\end{array}$ & $\begin{array}{l}\text { Incremental } \\
\text { internationalization; } \\
\text { Experiential learning }\end{array}$ & $\begin{array}{l}\text { Organizational } \\
\text { evolution; } \\
\text { Organizational } \\
\text { learning; Contingency } \\
\text { view }\end{array}$ \\
\hline$\downarrow$ & $\downarrow$ & $\downarrow$ & $\downarrow$ \\
\hline $\begin{array}{l}\text { - Theoretical } \\
\text { arguments: } \\
\text { - Benefits of } \\
\text { internationalization: } \\
\text { exploitation of FSAs, } \\
\text { and intangible assets } \\
\text { in international } \\
\text { markets. } \\
\text { - Other arguments: } \\
\text { operational } \\
\text { flexibility, economies } \\
\text { of scale and scope, } \\
\text { and risk } \\
\text { diversification. } \\
\text { Empirical findings: } \\
\text { Positive linear M-P } \\
\text { relationship. }\end{array}$ & $\begin{array}{l}\text { - Theoretical } \\
\text { arguments: } \\
\text { - Risks and barriers of } \\
\text { internationalization; } \\
\text { high coordination } \\
\text { costs caused by a high } \\
\text { degree of complexity. } \\
\text { - Costs of liabilities of } \\
\text { foreignness. } \\
\text { - Empirical findings: } \\
\text { Negative linear M-P } \\
\text { relationship. }\end{array}$ & $\begin{array}{l}\text { - Theoretical } \\
\text { arguments: } \\
\text { - Benefits and costs of } \\
\text { internalization as it is } \\
\text { an incremental process } \\
\text { with learning from } \\
\text { past experience and } \\
\text { knowledge. } \\
\text { - Periods of positive } \\
\text { benefits and periods of } \\
\text { high costs of } \\
\text { internationalization. } \\
\text { - Empirical findings: } \\
\text { Inverted U-shaped, } \\
\text { and J-shaped } \\
\text { relationship. }\end{array}$ & $\begin{array}{l}\text { - Theoretical } \\
\text { arguments: } \\
\text { - Benefits and costs as } \\
\text { a result of evolution of } \\
\text { the organization; } \\
\text { organizational } \\
\text { learning; innovation } \\
\text { and knowledge } \\
\text { development. } \\
\text { - A curve of negative- } \\
\text { positive-negative } \\
\text { effects of } \\
\text { internationalization. } \\
\text { - Empirical findings: } \\
\text { S- and inverted S- } \\
\text { shaped relationship. }\end{array}$ \\
\hline$\downarrow$ & $\downarrow$ & $\downarrow$ & $\downarrow$ \\
\hline
\end{tabular}

Results of our review analysis: Six inconsistencies

(1) A wide variety of theoretical perspectives used to advocate for a particular model, and inconclusive empirical results.

(2) Differences in conceptualization and measurements of $\mathrm{M}$.

(3) Differences in conceptualization and measurements of P.

(4) Inconclusive findings on the M-P relationships with different functional forms and shapes.

(5) An omission of risk-return trade- off.

(6) Methodological issues: a lack of diversity in geographic focus (research contexts) and a lack of comparative studies.

\section{$\sqrt{1}$}

\section{Our suggestions for future research directions}

(1) The determinant of a firm's performance is firm-specific advantages (FSAs), not multinationality per se.

(2) There is a reverse effect of profitability and overall performance on FSAs.

(3) Replace the traditional measures of multinationality by geographic segment (regional) measures in accordance with accounting standards in operating segment reporting and disclosures (IFRS8 and US GAAP FASB131).

(4) Focus on a clear analysis of the effects of home country operations on return on home assets (ROHA), and the effects of international operations on return on foreign assets (ROFA), instead of examining the effects of multinationality on return on total assets (ROTA) as in the current literature.

(5) Use alternative value-based performance measures, such as economic value added (EVA) and cash flow return on investment (CFROI).

(6) Incorporate finance factors in future research design.

(7) Need to research for other countries than the United States context, and the requirement of comparative studies and cross-country analysis.

(8) Examine the phenomenon from a subsidiary-level perspective. 
Table 1: Distribution of articles in publication outlets

\begin{tabular}{|c|c|c|}
\hline No. & Publication outlets & Number of studies \\
\hline 1 & Journal of International Business Studies & 23 \\
\hline 2 & Management International Review & 18 \\
\hline 3 & Strategic Management Journal & 10 \\
\hline 4 & International Business Review & 8 \\
\hline 5 & Academy of Management Journal & 8 \\
\hline 6 & Multinational Business Review & 8 \\
\hline 7 & $\begin{array}{l}\text { Classic books (Hymer, 1960; Vernon, 1971; Stopford \& Well, 1972; Kumar, 1984; } \\
\text { Dunning, 1985; Rugman et al., 1985; Yoshihara, 1985) }\end{array}$ & 7 \\
\hline 8 & Global Strategy Journal & 6 \\
\hline 9 & Journal of Business Research & 4 \\
\hline 10 & Journal of International Management & 4 \\
\hline 11 & Journal of Management & 3 \\
\hline 12 & Journal of Finance & 3 \\
\hline 13 & British Journal of Management & 2 \\
\hline 14 & Journal of World Business & 2 \\
\hline 15 & Journal of Financial and Quantitative Analysis & 2 \\
\hline 16 & Journal of American Academy of Business & 2 \\
\hline 17 & Asia Pacific Journal of Management & 2 \\
\hline 18 & Corporate Finance Review & 2 \\
\hline 19 & The Quarterly Review of Economics and Finance & 1 \\
\hline 20 & Research in Global Strategic Management & 1 \\
\hline 21 & International Journal of Management Reviews & 1 \\
\hline 22 & Journal of Business Venturing & 1 \\
\hline 23 & Journal of Global Marketing & 1 \\
\hline 24 & Journal of Transnational Management & 1 \\
\hline 25 & Sloan Management Review & 1 \\
\hline 26 & The Journal of Business & 1 \\
\hline 27 & Advances in International Competitive Management & 1 \\
\hline 28 & The International Journal of Organizational Analysis & 1 \\
\hline 29 & The International Trade Journal & 1 \\
\hline 30 & Applied Economics & 1 \\
\hline 31 & Oxford Bulletin of Economics and Statistics & 1 \\
\hline 32 & The Review of Economics and Statistics & 1 \\
\hline 33 & European Journal of International Management & 1 \\
\hline 34 & Applied Economics Letter & 1 \\
\hline 35 & International Journal of Commerce and Management & 1 \\
\hline 36 & Journal of International Financial Management and Accounting & 1 \\
\hline 37 & International Review of Financial Analysis & 1 \\
\hline 38 & Journal of Korea Trade & 1 \\
\hline \multirow[t]{2}{*}{39} & Schmalenbach Business Review & 1 \\
\hline & Total & 135 \\
\hline
\end{tabular}


Table 2: Distribution of types of articles

\begin{tabular}{lll}
\hline No. & Types of articles & Number of studies \\
\hline 1 & Conceptual & 11 \\
2 & Conceptual and empirical (classic books) & 7 \\
3 & Review & 9 \\
4 & Meta-analysis & 6 \\
5 & Empirical & 102 \\
\hline
\end{tabular}




\section{Table 3: Distribution of articles by geographic focus}

\begin{tabular}{|c|c|}
\hline Articles and classic books & Geographic focus \\
\hline $\begin{array}{l}\text { Hymer (1960); Vernon (1971); Stopford and Wells (1972); Horst (1972); Severn and } \\
\text { Laurence (1974); Hughes et al. (1975); Rugman (1976); Errunza and Senbet (1981); } \\
\text { Siddharthan and Lall (1982); Kim and Lyn (1986); Michel and Shaked (1986); } \\
\text { Shaked (1986); Daniels and Bracker (1989); Benvigvati (1987); Kim et al. (1989); } \\
\text { Collins (1990); Jung (1991); Morck and Yeung (1991); Kim et al. (1993); Sullivan } \\
\text { (1994a); Sullivan, D. (1994b); Ramaswamy (1995); Sambharya (1995); Allen and } \\
\text { Pantzalis (1996); Tallman and Li (1996); Ramaswamy et al. (1996); Gomez-Mejia } \\
\text { and Palich (1997); Hitt et al. (1997); Qian (1997); Qian (1998); Riahi-Belkaoui } \\
\text { (1998); Reeb et al. (1998); Gomes and Ramaswamy (1999); Elango (2000); Zahra et } \\
\text { al (2000); Pantzalis (2001); Whited (2001); Denis et al. (2002); Kotabe et al. (2002); } \\
\text { Qian (2002); Qian and Li (2002); Click and Harrison (2002); Bae and Jain (2003); } \\
\text { Contractor et al. (2003); Thomas and Eden (2004); Li (2005); Li and Qian (2005); } \\
\text { Christophe and Lee (2005); Doukas and Kan (2006); Hitt et al. (2006); Rugman and } \\
\text { Sukpanich (2006); Chang and Wang (2007); Qian et al. (2008); Bae et al., (2008); } \\
\text { Kim and Mathur (2008); Dastidar (2009); Gande et al. (2009); Wang et al. (2011); } \\
\text { Powell (2013); Oh and Contractor (2014) }\end{array}$ & $\begin{array}{l}\text { North America } \\
\text { The United States } \\
\text { (60 studies) }\end{array}$ \\
\hline Marthur et al (2001) & Canada (1 study) \\
\hline Rugman and Oh (2010); Rugman and Oh (2011); de Jong and van Houten (2014) & Europe (3 studies) \\
\hline $\begin{array}{l}\text { Kumar (1984); Dunning (1985); Grant (1987); Grant et al (1988); Rugman et al. } \\
\text { (2008) }\end{array}$ & $\begin{array}{l}\text { The United Kingdom ( } 5 \\
\text { studies) }\end{array}$ \\
\hline $\begin{array}{l}\text { Buehner (1987); Capar and Kotabe (2003); Ruigrok and Wagner (2003); Eckert et } \\
\text { al. (2010); Fisch and Zschoche (2011a, b) }\end{array}$ & Germany (6 studies) \\
\hline Ramirer - Aleson and Espitia-Escuer (2001) & Spain (1 study) \\
\hline Ruigrok et al. (2007) & Switzerland (1 study) \\
\hline $\begin{array}{l}\text { Yoshihara (1985); Delios and Beamish (1999); Geringer et al. (2000); Goerzen and } \\
\text { Beamish (2003); Lu and Beamish (2004); Tallman et al. (2004); Kim et al. (2004); }\end{array}$ & Japan (7 studies) \\
\hline Contactor et al. (2007); Pattnaik and Elango (2009) & India (2 studies) \\
\hline Lin et al. (2005) & Singapore (1 study) \\
\hline Wan (1998) & Hong Kong (1 study) \\
\hline Chiang and Yu (2005) & Taiwan (1 study) \\
\hline Thomas (2006) & Mexico (1 study) \\
\hline Kim (2009); Lee, Kim and Davidson (2015) & Korea (2 studies) \\
\hline Brock and Yaffe (2008); Hall \& Rutherford (2003) & $\begin{array}{l}\text { Largest petroleum } \\
\text { enterprises (1 study) } \\
U S \& U K ; U S \& \text { Korea } \\
\text { (2 studies) }\end{array}$ \\
\hline $\begin{array}{l}\text { Rugman et al. (1985); Geringer et al. (1989); Gedajlovic and Shapiro (1998); } \\
\text { Annavarjula et al. (2005); Rugman and Sukpanich (2006); Elango and Sethi (2007); } \\
\text { Hutzschenreuter and Voll (2008); Ferris et al. (2010); Aggarwal et al. (2011); Yang } \\
\text { et al. (2013); }\end{array}$ & $\begin{array}{l}\text { Multiple countries } \\
\text { (aggregated analysis) }\end{array}$ \\
\hline
\end{tabular}


Table 4: Summary of previous meta-analysis, literature review, and conceptual articles on the M-P relationships

\begin{tabular}{|c|c|c|c|c|}
\hline Studies & Types & $\begin{array}{l}\text { Sampling and } \\
\text { Focus }\end{array}$ & Findings & Suggestions for future research \\
\hline $\begin{array}{l}\text { Bausch, A. \& } \\
\text { Krist, A. (2007) }\end{array}$ & Meta-analysis & $\begin{array}{l}36 \text { papers of } \\
\text { MNEs, and } \\
\text { SMEs. } \\
\text { Focus: the effects } \\
\text { of context-related } \\
\text { moderators on the } \\
\text { M-P relationship }\end{array}$ & 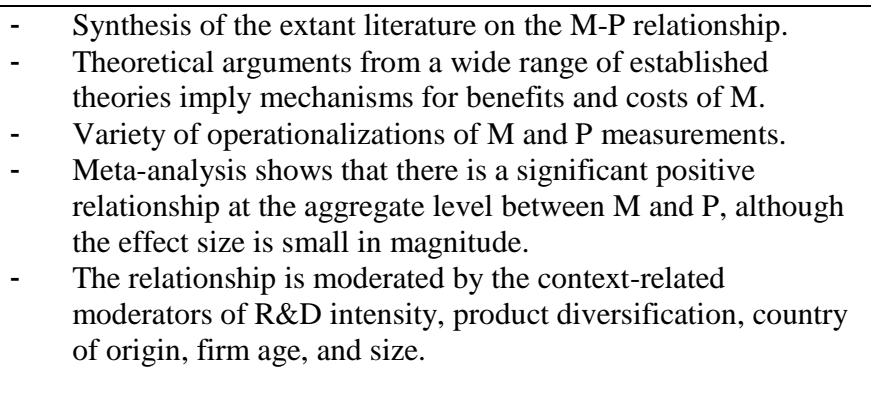 & $\begin{array}{l}\text { - Future research should not look for M-P } \\
\text { generalizations, but instead develop more fine- } \\
\text { grained models, i.e. the conditions under which M } \\
\text { might be fruitful. } \\
\text { Consideration of other contextual factors on size of } \\
\text { effect: industry, competition, exchange fluctuation, } \\
\text { and strategic action variables, e.g. entry mode } \\
\text { choice, composition of senior management and } \\
\text { incentive system, and differences in the } \\
\text { internationalization process itself contributing to } \\
\text { performance differences. }\end{array}$ \\
\hline $\begin{array}{l}\text { Kirca, A.H., } \\
\text { Hult, G.T.M., } \\
\text { Roth, K., } \\
\text { Cavusgil, S.T., } \\
\text { Perry M.Z., } \\
\text { Akdeniz, M.B., } \\
\text { Deligonul, S.Z., } \\
\text { Mena, J., A, } \\
\text { Pollitte, W. A., } \\
\text { Hoppner, J.J., } \\
\text { Miller, J.C. \& } \\
\text { White, R.C. } \\
\text { (2011) }\end{array}$ & Meta-analysis & $\begin{array}{l}120 \text { independent } \\
\text { samples reported } \\
\text { in } 111 \text { papers of } \\
\text { MNEs, SMEs, } \\
\text { INVs, } \\
\text { internationalizatio } \\
\text { n of top } \\
\text { management team } \\
\text { (TMT). } \\
\text { Focus: firm- } \\
\text { specific assets, } \\
\text { multinationality } \\
\text { (M), and financial } \\
\text { performance }\end{array}$ & $\begin{array}{l}\text { Draw upon internalization theory to examine FSAs, M, and P } \\
\text { relationships: FSAs and M relationship; the mediating effect } \\
\text { of M on FSAs and P; the moderating effect of FSAs on M and } \\
\text { P; FSAs, M, P relationship in the context of industries (R\&D } \\
\text { intensive versus marketing intensive in manufacturing and } \\
\text { service industries; high-tech and low-tech industries), and } \\
\text { countries (advanced versus developing economies), while } \\
\text { controlling for strategic firm resources (firm size, international } \\
\text { experience, age, product diversification). } \\
\text { Measurements for FSAs: R\&D, advertising; Multinationality; } \\
\text { Performance (P): ROA, sales, ROS, profitability, sales } \\
\text { growth, ROE, Tobin's q, ROI. } \\
\text { Multinationality provides an efficient organizational form to } \\
\text { transfer FSAs which have positive impacts on firm } \\
\text { performance. } \\
\text { M has intrinsic value above and beyond FSAs. }\end{array}$ & $\begin{array}{l}\text { Investigation of M-P relationship in conjunction } \\
\text { with marketing standardization programme, entry } \\
\text { mode choice, scale of entry, speed of } \\
\text { internationalization. }\end{array}$ \\
\hline
\end{tabular}


Table 4: Summary of previous meta-analysis, literature review, and conceptual articles on the M-P relationships (continued)

\begin{tabular}{|c|c|c|c|c|}
\hline Studies & Types & $\begin{array}{l}\text { Sampling and } \\
\text { Focus }\end{array}$ & Findings & Suggestions for future research \\
\hline $\begin{array}{l}\text { Kirca, A.H, } \\
\text { Roth, K., Hult, } \\
\text { T.M, \& } \\
\text { Cavusgil, S.T. } \\
\text { (2012) }\end{array}$ & Meta-analysis & $\begin{array}{l}152 \text { independent } \\
\text { samples reported } \\
\text { in } 141 \\
\text { papers of MNEs, } \\
\text { SMEs, INVs, } \\
\text { internationalizatio } \\
\mathrm{n} \text { of top } \\
\text { management team } \\
\text { (TMT). } \\
\text { Focus: the role of } \\
\text { context in the M- } \\
\text { P relationship. }\end{array}$ & $\begin{array}{l}\text { Examine the moderating effects of firm-level (firm size, type } \\
\text { of firm, breadth versus depth of multinationality, motivations } \\
\text { of revenue generation versus profit maximization, stage of } \\
\text { firm internationalization at the threshold of FS/TS); industry- } \\
\text { level (service versus manufacturing sectors); and country- } \\
\text { level factors (developed versus developing countries) on the } \\
\text { M-P relationship. } \\
\text { Findings: the effects of M on P depend on type of M, firm } \\
\text { strategic motivations, industry characteristics, and home } \\
\text { country factors. } \\
\text { Firm size and stage of internationalization are not significant } \\
\text { moderators. } \\
\text { The search for more complex M-P relationships (i.e., U- } \\
\text { shaped, inverse U-shaped, horizontal S-curve) has the } \\
\text { potential to expand our understanding, only when the } \\
\text { characteristics of different research contexts, measurement } \\
\text { issues, and firm characteristics are taken into account in the } \\
\text { theoretical development and research design stages of studies. }\end{array}$ & 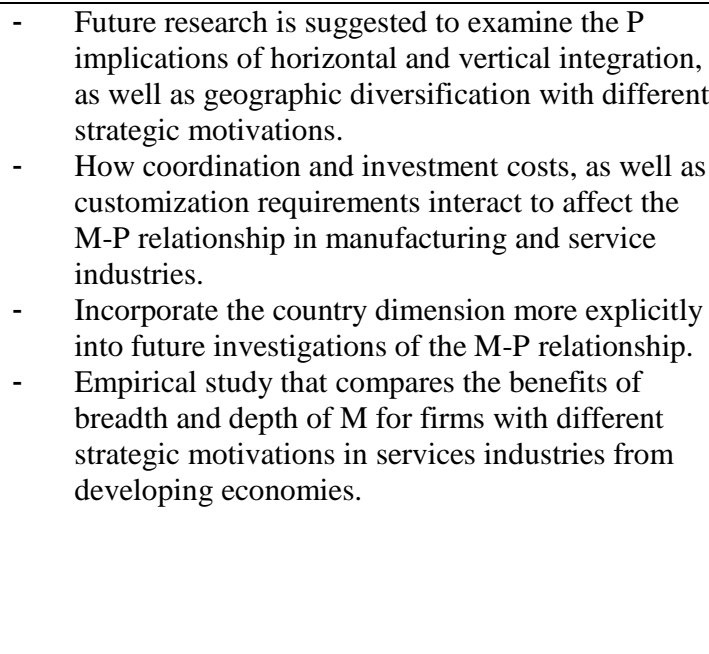 \\
\hline $\begin{array}{l}\text { Yang, Y. \& } \\
\text { Driffield (2012) }\end{array}$ & Meta-analysis & $\begin{array}{l}54 \text { papers of } \\
\text { MNEs } \\
\text { Focus: a meta- } \\
\text { analysis of M-P } \\
\text { literature }\end{array}$ & $\begin{array}{l}\text { - When analysis is based on non-US data, the reported return to } \\
\text { M is higher. This relationship for non-US firms is usually U- } \\
\text { shaped rather than inverted U-shaped. } \\
\text { US firms have lower returns to M than other firms but are less } \\
\text { likely incur losses in the early stages of internationalization. } \\
\text { Differences are reported when comparing regression and non- } \\
\text { regression based techniques (e.g. ANOVA, t-tests). } \\
\text { Other characteristics influence the estimate rate of return and } \\
\text { its shape across different studies: M measurement; size } \\
\text { distribution of the sample, market-based P indicators. } \\
\text { No evidence of publication bias. }\end{array}$ & $\begin{array}{l}\text { Future research using meta-analysis needs to pay } \\
\text { more attention to theoretical arguments, } \\
\text { measurements, sampling, and methodological } \\
\text { differences when comparing findings with other } \\
\text { studies in the M-P literature. }\end{array}$ \\
\hline
\end{tabular}


Table 4: Summary of previous meta-analysis, literature review, and conceptual articles on the M-P relationships (continued)

\begin{tabular}{|c|c|c|c|c|}
\hline Studies & Types & $\begin{array}{l}\text { Sampling and } \\
\text { Focus }\end{array}$ & Findings & Suggestions for future research \\
\hline $\begin{array}{l}\text { Annavarjula, } \\
\text { M. \& Beldona, } \\
\text { S. (2000) }\end{array}$ & $\begin{array}{l}\text { Literature } \\
\text { review }\end{array}$ & $\begin{array}{l}26 \text { papers of } \\
\text { MNEs. } \\
\text { Focus: M-P } \\
\text { relationship: } \\
\text { review and } \\
\text { reconceptualizatio } \\
\mathrm{n}\end{array}$ & 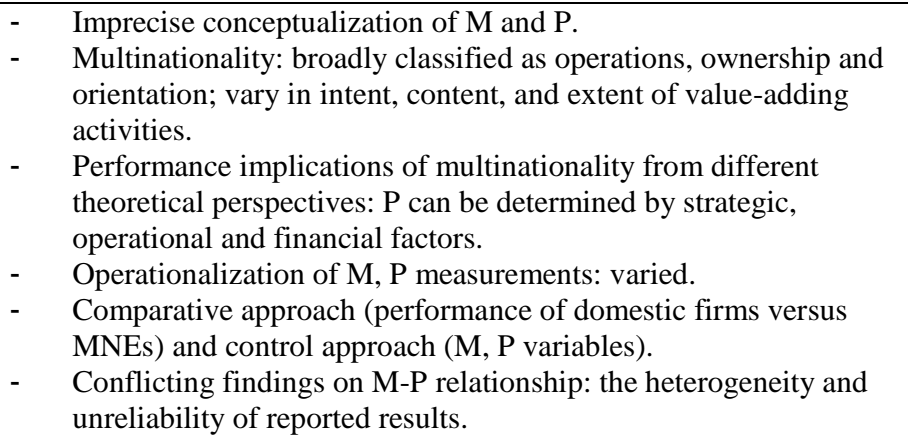 & $\begin{array}{l}\text { The } \mathrm{M} \text { concept needs to be refined to include } \\
\text { the multidimensionality of its meaning, and the } \\
\mathrm{P} \text { concept needs to be refined within this } \\
\text { context. }\end{array}$ \\
\hline $\begin{array}{l}\text { Hitt, M.A., } \\
\text { Tihanyi, L., } \\
\text { Miller, T. \& } \\
\text { Connelly, B. } \\
\text { (2006) }\end{array}$ & $\begin{array}{l}\text { Literature } \\
\text { review }\end{array}$ & $\begin{array}{l}58 \text { papers of } \\
\text { MNEs, SMEs, } \\
\text { INVs, } \\
\text { internationalizatio } \\
\text { n of top } \\
\text { management team } \\
\text { (TMT). } \\
\text { Focus: } \\
\text { International } \\
\text { diversification } \\
\text { (ID) antecedents, } \\
\text { outcomes, and } \\
\text { moderators }\end{array}$ & $\begin{array}{l}\text { - International diversification (ID) as a strategy of the firm. } \\
\text { - Antecedents: TMT characteristics, board composition, } \\
\text { organizational structure and size, ownership strategic elements, } \\
\text { processes and resources. } \\
\text { - Characteristics of ID: scale, scope, dimensions (structural, } \\
\text { performance, attitudinal) } \\
\text { - Moderating environmental factors: home, host country resources, } \\
\text { institutional environment, task environment, industry competitive } \\
\text { environment, uncertainty. } \\
\text { - } \quad \begin{array}{l}\text { Performance outcomes: accounting, market, growth } \\
\text { - }\end{array} \text { Other moderators: product diversification, organizational } \\
\text { characteristics, TMT experience and diversity. } \\
\text { - } \quad \begin{array}{l}\text { Process and organizational outcomes: innovation, learning, } \\
\text { organizational structures, operating efficiency, risk, debt. }\end{array} \\
\text { - } \quad \text { Synthesis of research on ID: } \\
\text { - Theories and relationships: a broad range of theoretical } \\
\text { perspectives. } \\
\text { - Characteristics and measurement of ID: varied. } \\
\text { Measurement of performance: varied. }\end{array}$ & $\begin{array}{ll}\text { - } & \text { New theoretical perspectives. } \\
\text { - } & \text { Exploration of potential antecedents, } \\
\text { mediators, moderators, and outcomes of ID. } \\
\text { - } & \text { Multi-level analysis. } \\
\text { - } & \text { Refined measures. } \\
\text { Additional motives and outcomes: e.g. } \\
\text { behaviours of outlier firms; divestment and } \\
\text { divestures; operating mode change. } \\
\text { - } \quad \text { TMT, governance, and ID. } \\
\text { - } \quad \text { Executive decision making process of ID. } \\
\text { - } \quad \text { The role of institutional environments in ID } \\
\text { - } \quad \text { Fecisions. } \\
-\quad \text { Methodogitimacy. } \\
-\quad \text { Inter-organizational perspectives on ID. } \\
-\quad \text { The need for more extensive longitudinal } \\
\text { studies. } \\
\text { Mediators between antecedents and outcomes. }\end{array}$ \\
\hline
\end{tabular}


Table 4: Summary of previous meta-analysis, literature review, and conceptual articles on the M-P relationships (continued)

\begin{tabular}{|c|c|c|c|c|}
\hline Studies & Types & $\begin{array}{l}\text { Sampling and } \\
\text { Focus }\end{array}$ & Findings & Suggestions for future research \\
\hline Li, L. (2007) & $\begin{array}{l}\text { Literature } \\
\text { review }\end{array}$ & $\begin{array}{l}43 \text { papers of } \\
\text { MNEs and SMEs } \\
\text { Focus: M-P } \\
\text { relationship } \\
\text { literature review }\end{array}$ & 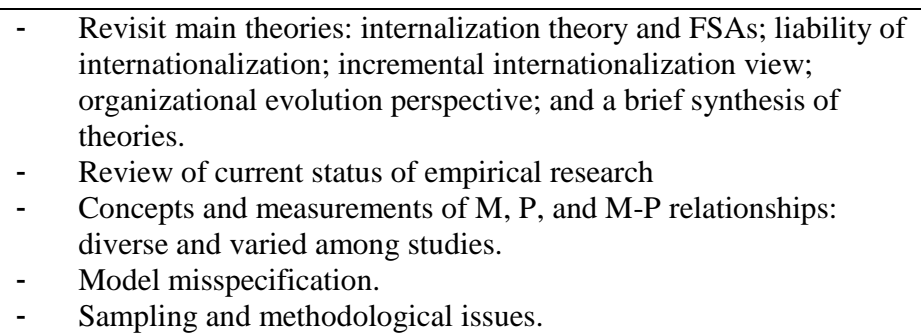 & $\begin{array}{ll}\text { - } & \text { Conceptual refinement of and measurement of } \\
\text { M. } & \text { Cost-efficiency implications of M. } \\
\text { - } & \text { Impact of internationalization motivations on } \\
\text { - } & \text { Two-way } \mathrm{P} \text {. } \\
\text { - } & \text { Moderating roles of external and internal } \\
\text { - } & \text { contextual factors. } \\
\text { Internationalization motives. }\end{array}$ \\
\hline $\begin{array}{l}\text { Matyisak, L. \& } \\
\text { Bausch, A. } \\
\text { (2012) }\end{array}$ & $\begin{array}{l}\text { Literature } \\
\text { review }\end{array}$ & $\begin{array}{l}63 \text { papers of } \\
\text { MNEs. } \\
\text { Focus: } \\
\text { Antecedents of } \\
\text { MNE } \\
\text { performance }\end{array}$ & $\begin{array}{l}\text { Integration of strategic management and international business } \\
\text { perspectives on antecedents of MNE performance at multiple } \\
\text { levels of analysis. } \\
\text { - } \quad \text { Industry level antecedents: market-based view. } \\
\text { - Firm-level antecedents: resource-based view, internalization } \\
\text { theory. } \\
\text { - } \quad \begin{array}{l}\text { Country-level antecedents: Rugman's CSAs/FSAs; liability of } \\
\text { foreignness. }\end{array} \\
\text { - } \quad \begin{array}{l}\text { Use of contradicting and competing theories to substantiate the } \\
\text { contended arguments and a lack of consistent, coherent and }\end{array} \\
\text { parsimonious theoretical framework. } \\
\text { Diverse dimensions of P measures used without consideration of } \\
\text { potential implications of choosing one over another. } \\
\text { - Extremely narrow focus in explanatory variables, dominated by M } \\
\text { measures. } \\
\text { Empirical results: inconclusive, conflicting, and inconsistent with } \\
\text { different findings. } \\
\text { MNEs need FSAs and CSAs to benefit from M. }\end{array}$ & $\begin{array}{l}\text { Development of a comprehensive, coherent } \\
\text { and parsimonious theoretical framework for } \\
\text { antecedents of MNE performance. } \\
\text { Building such work on internalization theory } \\
\text { instead of an omnium-gatherum of various } \\
\text { contradicting and competing theoretical } \\
\text { arguments: a promising starting point. }\end{array}$ \\
\hline
\end{tabular}


Table 4: Summary of previous meta-analysis, literature review, and conceptual articles on the M-P relationships (continued)

\begin{tabular}{|c|c|c|c|c|}
\hline Studies & Types & $\begin{array}{l}\text { Sampling and } \\
\text { Focus }\end{array}$ & Findings & Suggestions for future research \\
\hline $\begin{array}{l}\text { Glaum, M. \& } \\
\text { Oesterle, M-J. } \\
(2007)\end{array}$ & $\begin{array}{l}\text { Conceptual } \\
\text { paper }\end{array}$ & $\begin{array}{l}\text { Focus: an } \\
\text { overview of M-P } \\
\text { relationship }\end{array}$ & $\begin{array}{l}\text { - Introduction to a special issue of MIR: an overview of alternative } \\
\text { approaches to the modelling of M-P relationship; reasons for } \\
\text { contradictory results of past research; suggestions for future } \\
\text { research. } \\
40 \text { years of research on internationalization and firm performance: } \\
\text { more questions than answers? } \\
\text { Theoretical foundation: should we expect a positive relationship } \\
\text { between M and firm performance? The heterogeneity of different } \\
\text { countries (e.g. size of home market). } \\
\text { - Modelling the relationship between M and P: other strategic } \\
\text { considerations. } \\
\text { Operationalizing M and P: the fit between theoretical arguments } \\
\text { and measurements. }\end{array}$ & $\begin{array}{ll}\text { - } & \text { Clinical case studies which focus on individual } \\
\text { firms and their specific internationalization } \\
\text { processes and experiences over time and } \\
\text { performance. } \\
\text { - } \quad \text { Multi-dimensional nature of M and P. } \\
\text { - } \quad \text { Studies of industry-level studies. } \\
\text { - }\end{array}$ \\
\hline $\begin{array}{l}\text { Oesterle, M-J \& } \\
\text { Richta (2013) }\end{array}$ & $\begin{array}{l}\text { Literature } \\
\text { review }\end{array}$ & $\begin{array}{l}38 \text { papers of } \\
\text { MNEs. } \\
\text { Focus: M-P } \\
\text { empirical research }\end{array}$ & $\begin{array}{l}\text { Theoretical foundation: a wide range of theories or a combination } \\
\text { of multiple theories. Ambiguous underlying assumptions in } \\
\text { theoretical arguments. Major weakness: eclecticism, e.g. poor } \\
\text { synthesis of theories; assumption of one ideal type of } \\
\text { internationalization; mix up of the time dimension and } \\
\text { multinationality in the S-curve model; disregard of moderating } \\
\text { effects. } \\
\text { Empirical approaches: vary greatly. } \\
\text { - } \text { M measurements: the fit between theoretical arguments and } \\
\text { operationalization of } \mathrm{M} \text { is questionable; no generally accepted } \\
\text { criteria; construct validity concerns; both uni-dimensional } \\
\text { measures (depth and breadth) and multi-dimensional measures } \\
\text { have weaknesses; model-based problems. } \\
\text { P measurements: accounting-based and market-based measures; } \\
\text { concerns on underlying assumptions of firms are driven solely by } \\
\text { economic results. Explanatory power of performance measure: } \\
\text { short-term versus long-term. Causality of firm performance by } \\
\text { other financial market transactions. } \\
\text { Neglect of the process characteristics of internationalization: } \\
\text { cross-section versus longitudinal data. } \\
\text { Data availability: a general problem of empirical research. }\end{array}$ & $\begin{array}{l}\text { - Theoretically clear and broadly accepted concepts } \\
\text { of the constructs M, P. } \\
\text { - Clear links between theoretical arguments and } \\
\text { empirical testing. } \\
\text { - Consideration of internationalization process. } \\
\text { - Qualitative, case-study approach. } \\
\text { - Longitudinal versus cross-section data. }\end{array}$ \\
\hline
\end{tabular}


Table 4: Summary of previous meta-analysis, literature review, and conceptual articles on the M-P relationships (continued)

\begin{tabular}{|c|c|c|c|c|}
\hline Studies & Types & $\begin{array}{l}\text { Sampling and } \\
\text { Focus }\end{array}$ & Findings & Suggestions for future research \\
\hline $\begin{array}{l}\text { Hennart, J-F. } \\
\text { (2007) }\end{array}$ & $\begin{array}{l}\text { Conceptual } \\
\text { paper }\end{array}$ & $\begin{array}{l}\text { Focus: theoretical } \\
\text { debate }\end{array}$ & $\begin{array}{l}\text { Review and critical evaluation of the main theoretical arguments } \\
\text { in the extant literature for a positive M-P relationship: } \\
\text { international diversification and risk reduction; multinationality } \\
\text { and profitability based on arguments of the economies of scale; } \\
\text { the flexibility; the learning effects. } \\
\text { Methodological issues: contradictions between theoretical } \\
\text { arguments and operationalization of the main independent } \\
\text { variable, international diversity and a lack of adequate control } \\
\text { variables. } \\
\text { Transaction cost/ internalization (TCI) theory implies no direct } \\
\text { and general relationship between M and P. }\end{array}$ & $\begin{array}{l}\text { Future studies should be performed at a lower } \\
\text { level of aggregation, e.g. a detailed industry } \\
\text { level. This allows control for the size of an } \\
\text { MNE's home market, the cultural diversity of } \\
\text { the markets it has entered, and intangibles. } \\
\text { Comparisons of firms within a given industry, } \\
\text { following similar strategies and having similar } \\
\text { cost curves with similar minimum efficient } \\
\text { scale (MES), but based in home markets of } \\
\text { different sizes: costs and benefits of ID. } \\
\text { - Use longitudinal data to test the three-stage } \\
\text { model. } \\
\text { The role of management; strategies and } \\
\text { organizational structures in M-P. } \\
\text { Confronting M-P arguments with the } \\
\text { prediction of other theories. }\end{array}$ \\
\hline $\begin{array}{l}\text { Bowen, H.P. } \\
\text { (2007) }\end{array}$ & $\begin{array}{l}\text { Conceptual } \\
\text { paper }\end{array}$ & $\begin{array}{l}\text { Focus: the } \\
\text { empirics of M-P } \\
\text { relationship }\end{array}$ & $\begin{array}{l}\text { Statistical issues concerning the empirical estimation of M-P } \\
\text { relationship (e.g. (cross-sectional versus panel data; fixed and } \\
\text { random effects; omitted firm specific characteristics; model } \\
\text { heterogeneity; endogenous regressors; sample selection bias; } \\
\text { cross-sectional variation and time-series behaviour). } \\
\text { These problems appear to need resolution but have been largely } \\
\text { neglected in the IB literature. } \\
\text { Among these are endogeneity of the M construct in the P } \\
\text { relationship and the likelihood that the M-P relationship is } \\
\text { heterogeneous across firms. }\end{array}$ & $\begin{array}{l}\text { Developing more specific models of } \\
\text { multinationality, and employing techniques } \\
\text { which made use of the richness of longitudina } \\
\text { data. } \\
\text { A better delineation of the different modes of } \\
\text { multinationality. } \\
\text { - Untangling the different sources of } \\
\text { performance which are encapsulated in the } \\
\text { underlying theoretical explanations. }\end{array}$ \\
\hline
\end{tabular}


Table 4: Summary of previous meta-analysis, literature review, and conceptual articles on the M-P relationships (continued)

\begin{tabular}{|c|c|c|c|c|}
\hline Studies & Types & $\begin{array}{l}\text { Sampling and } \\
\text { Focus }\end{array}$ & Findings & Suggestions for future research \\
\hline $\begin{array}{l}\text { Contractor, F. } \\
(2007)\end{array}$ & $\begin{array}{l}\text { Conceptual } \\
\text { paper }\end{array}$ & $\begin{array}{l}\text { Focus: theoretical } \\
\text { debate }\end{array}$ & $\begin{array}{l}\text { A general theory of international expansion and its effect on the } \\
\text { performance of firms: three-stage S-curve model. } \\
\text { Using the lens of this theory, it addresses the question why most } \\
\text { companies are regional, in the sense that their geographic } \\
\text { coverage seems to be far from complete. } \\
\text { Discussion of the lack of congruence in M-P empirical findings: } \\
\text { different measurements of P; M; different modes of entry; } \\
\text { different sectors; different countries of origin; firms based in } \\
\text { emerging economies; other context-dependence and reconciliation } \\
\text { through the 3-stage model. } \\
\text { The arguments are that the apparently contradictory results of past } \\
\text { studies are but subsets of the three stages of the general theory. }\end{array}$ & $\begin{array}{l}\text { Exploration of micro factors which create the } \\
\text { liability of foreignness. } \\
\text { Why is the liability of foreignness small for } \\
\text { some companies but persistent in others? } \\
\text { Will companies in emerging markets face } \\
\text { greater costs of internationalization because of } \\
\text { cultural and geographic distance from major } \\
\text { markets, and because of the smaller scale of } \\
\text { home country markets? } \\
\text { What determines the inflexion points between } \\
\text { the three stages of international expansion? } \\
\text { Why do some companies over- } \\
\text { internationalize? Is it conscious? Is there } \\
\text { hysteresis? } \\
\text { How many companies are conscious of an } \\
\text { optimal DOI as a management or strategy } \\
\text { issue? } \\
\text { Limits to internationalization, in terms of } \\
\text { dissection of administration and coordination } \\
\text { costs. } \\
\text { More studies on the international path of } \\
\text { service-sector companies based in emerging } \\
\text { and smaller nations. } \\
\text { Longitudinal studies. }\end{array}$ \\
\hline $\begin{array}{l}\text { Verbeke, A., } \\
\text { Li, L. \& } \\
\text { Goerzen, A. } \\
(2009)\end{array}$ & $\begin{array}{l}\text { Conceptual } \\
\text { paper }\end{array}$ & $\begin{array}{l}\text { Focus: theoretical } \\
\text { debate }\end{array}$ & $\begin{array}{l}\text { Past empirical work on M-P relationship is flawed from a } \\
\text { conceptual perspective since there is no valid theoretical rationale } \\
\text { that would predict a generalizable M-P relationship. } \\
\text { Revisit M-P relationship: three key parameters underlying the } \\
\text { substance of the M concept: variety of strategic motivations for } \\
\text { FDI, environmental complexity and organizational complexity. }\end{array}$ & $\begin{array}{l}\text { Useful empirical work on the M-P linkage in } \\
\text { future research requires prior analysis in } \\
\text { specific empirical settings. }\end{array}$ \\
\hline
\end{tabular}


Table 4: Summary of previous meta-analysis, literature review, and conceptual articles on the M-P relationships (continued)

\begin{tabular}{|c|c|c|c|c|}
\hline Studies & Types & $\begin{array}{l}\text { Sampling and } \\
\text { Focus }\end{array}$ & Findings & Suggestions for future research \\
\hline $\begin{array}{l}\text { Verbeke, A. \& } \\
\text { Brugman, P. } \\
\text { (2009) }\end{array}$ & $\begin{array}{l}\text { Conceptual } \\
\text { paper }\end{array}$ & $\begin{array}{l}24 \text { most-cited } \\
\text { papers of MNEs } \\
\text { and SMEs, and } 8 \\
\text { papers of S- } \\
\text { shaped curves. } \\
\text { Focus: theoretical } \\
\text { debate }\end{array}$ & $\begin{array}{l}\text { Adopt an internalization theory perspective to raise cautions } \\
\text { against assuming too quickly the S-curve model as a generalized } \\
\text { M-P relationship. } \\
\text { Firm-level performance depends primarily on the characteristics } \\
\text { of the companies' firm-specific advantages (FSAs), rather than on } \\
\text { the degree of M. } \\
\text { - Propose triple testing the quality of M-P studies: } \\
\text { - Test } 1 \text { : M of a) value chain activities; b) degree of } \\
\text { internationalization (DOI) versus diversification; c) related and } \\
\text { unrelated diversification. } \\
\text { Test 2: P of a) strategic investment motives; b) Appropriateness of } \\
\text { P measures; c) dynamic aspects. } \\
\text { Test 3: M-P linkages of a) use of cross-sectional versus } \\
\text { longitudinal data; b) testing P-M relationship c) endogeneity. }\end{array}$ & $\begin{array}{l}\text { Reverse causality and endogeneity: the most } \\
\text { critical challenges in M-P research. } \\
\text { - FSAs determine the firm's domestic and } \\
\text { international success, with the environment } \\
\text { acting as a constraining or facilitating force. } \\
\text { - } \quad \text { A case-based M-P research. } \\
\text { - Improve research design with careful } \\
\text { operationalization of the concepts and } \\
\text { measurements of M, P, and M-P relationship. } \\
\text { Business history case and theory are important } \\
\text { for well-grounded propositions instead of long } \\
\text { and speculative list of possible costs and } \\
\text { benefits of M which are not tested directly but } \\
\text { are merely enumerated to support allegedly } \\
\text { observed statistical curves. }\end{array}$ \\
\hline $\begin{array}{l}\text { Hult, G.T. } \\
\text { (2011) }\end{array}$ & $\begin{array}{l}\text { Commentary } \\
\text { in GSJ }\end{array}$ & $\begin{array}{l}\text { Focus: comments } \\
\text { on Hennart (2011) } \\
\text { and Wiersema \& } \\
\text { Bowen }(2011) \\
\text { with strategic } \\
\text { focus on M-P }\end{array}$ & $\begin{array}{l}\text { Review of Hennart (2011): Assessing the M-P literature: agree } \\
\text { with Hennart's view that deeper theoretical guidance when } \\
\text { studying M-P relationship is warranted. Firms do not achieve P } \\
\text { simply because of M. Firms achieve performance because they } \\
\text { were able to convert the positive aspects of M into something } \\
\text { valuable that, in turn, affects P. } \\
\text { Review of Wiersema and Bowen (2011): The puzzle remains. The } \\
\text { paper examines international diversification using data on the } \\
\text { pattern and evolution of exports and imports by US companies } \\
\text { and their foreign subsidiaries: incremental contributions in terms } \\
\text { of newness on the empirical literature. A different perspective on } \\
\text { the M-P literature, but does not reach any conclusive findings, nor } \\
\text { clarify any significant aspect of the relationship. }\end{array}$ & $\begin{array}{l}\text { Theoretically, } \mathrm{M} \text { has no effect on } \mathrm{P} \text { without } \\
\text { being converted, via action and/or behaviour, } \\
\text { into something of value first. The direct link (if } \\
\text { found significant), in essence, is a leap of faith } \\
\text { that conversion into value took place } \\
\text { somewhere along the } \mathrm{M} \text { to } \mathrm{P} \text { value chain. }\end{array}$ \\
\hline
\end{tabular}


Table 4: Summary of previous meta-analysis, literature review, and conceptual articles on the M-P relationships (continued)

\begin{tabular}{|c|c|c|c|c|}
\hline Studies & Types & $\begin{array}{l}\text { Sampling and } \\
\text { Focus }\end{array}$ & Findings & Suggestions for future research \\
\hline $\begin{array}{l}\text { Cardinal, L.B., } \\
\text { Miller, C.C., \& } \\
\text { Palich, L.E. } \\
(2011)\end{array}$ & $\begin{array}{l}\text { Literature } \\
\text { review and } \\
\text { commentary } \\
\text { in GSJ }\end{array}$ & $\begin{array}{l}35 \text { papers of } \\
\text { MNEs, SMEs. } \\
\text { Focus: Critique of } \\
\text { M-P literature and } \\
\text { commentary on } \\
\text { Hennart (2011) } \\
\text { and Wiersema \& } \\
\text { Bowen (2011) }\end{array}$ & $\begin{array}{l}\text { - } \begin{array}{l}\text { The international diversification (ID)-P research: forensic failures. } \\
\text { - }\end{array} \text { thalysis and critiques of the literature with particular emphasis on } \\
\text { the methodological aspects } \\
\text { - } \quad \text { A multiple-pronged prism to view IDP methodologies } \\
\text { Measurement approaches: conceptualization and } \\
\text { operationalization M; critique and comparison of existing models } \\
\text { (positive linear; U-shaped; inverted U-shaped; S-shaped models) } \\
\text { from statistical perspectives and empirical settings. } \\
\text { - Highlight the critical lessons by Hennart (2011) and Wiersema } \\
\text { and Bowen (2011). }\end{array}$ & 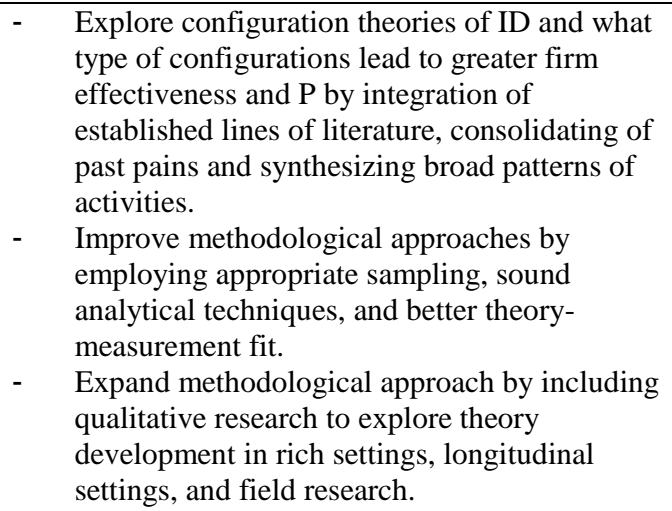 \\
\hline $\begin{array}{l}\text { Hennart, J-F. } \\
\text { (2011) }\end{array}$ & $\begin{array}{l}\text { Conceptual } \\
\text { paper in GSJ }\end{array}$ & $\begin{array}{l}\text { Focus: theoretical } \\
\text { debate }\end{array}$ & $\begin{array}{l}\text { - Assessment of the theoretical basis for the existence of a } \\
\text { relationship between the size of a firm's foreign footprint (its M) } \\
\text { and its P. } \\
\text { M results from a firm's choice between coordinating internally the } \\
\text { stages of its value chain and letting them be organized on the } \\
\text { market and hence that there are no reasons to expect net gains } \\
\text { from an increase or a decrease in M, the only profitability impact } \\
\text { from a firm having made the wrong choice and being over- or } \\
\text { under-integrated compared to the optimum. } \\
\text { The literature has operationalized M not matching the theoretical } \\
\text { arguments which it has advanced: ability to exploit intangibles; } \\
\text { ability to arbitrage; external and internal costs of foreignness. }\end{array}$ & $\begin{array}{l}\text { Investigate whether firms with more } \\
\text { internationally experienced top management } \\
\text { teams are better able to overcome the bias of } \\
\text { over- or under-internationalized relative to } \\
\text { the optimum/ a larger or a smaller foreign } \\
\text { footprint than optimal, and hence, are more fit } \\
\text { and profitable than their more parochial } \\
\text { competitors. If this were the case, one would } \\
\text { observe a linearly positive relationship between } \\
\text { M and P. }\end{array}$ \\
\hline
\end{tabular}


Table 4: Summary of previous meta-analysis, literature review, and conceptual articles on the M-P relationships (continued)

\begin{tabular}{|c|c|c|c|c|}
\hline Studies & Types & $\begin{array}{l}\text { Sampling and } \\
\text { Focus }\end{array}$ & Findings & Suggestions for future research \\
\hline $\begin{array}{l}\text { Wiersema, M. } \\
\text { F. \& Bowen, } \\
\text { H.P. (2011) }\end{array}$ & $\begin{array}{l}\text { Conceptual } \\
\text { and empirical } \\
\text { paper in GSJ }\end{array}$ & $\begin{array}{l}\text { Focus: M-P } \\
\text { relationship using } \\
\text { trade data }\end{array}$ & $\begin{array}{l}\text { The lack of consensus about the nature of the ID-P relationship } \\
\text { results from a failure to fully grasp this complex phenomenon. } \\
\text { - The paper uses data on trade flows of US companies and their } \\
\text { foreign subsidiaries to provide perspective on the activities of the } \\
\text { geographic scope of US companies. } \\
\text { Findings: overtime (1) firms' activities have become increasingly } \\
\text { narrow (specialized) and simultaneously geographically dispersed; } \\
\text { (2) firms export an increasing proportion of intermediary products } \\
\text { versus finished products; (3) intra-foreign subsidiary trade is } \\
\text { increasing; and (4) a small proportion of firms account for the } \\
\text { global activity of US firms. } \\
\text { Show the conceptualization of ID which encompasses the full } \\
\text { range of activities that determine the geographic scope. }\end{array}$ & $\begin{array}{l}\text { The problem of ID measurement (e.g. FS/TS } \\
\text { for ID) needs to be corrected as it is a key } \\
\text { source of the lack of connection between } \\
\text { theory and empirics. } \\
\text { The specification and testing for alternative } \\
\text { forms of the ID-P relationship: provides no } \\
\text { further insights into the nature of the } \\
\text { relationship. } \\
\text { The reliance on the commonly used single } \\
\text { measure of foreign sales ratio for ID does not } \\
\text { confer the measure with greater validity. } \\
\text { Sullivan (1994) composite indicator does not } \\
\text { resolve the problem of construct validity. } \\
\text { Construct credible measures of the operational } \\
\text { and organizational factors theoretically } \\
\text { predicted to emanate from ID and that then } \\
\text { create a differential impact on the P of the } \\
\text { firms. }\end{array}$ \\
\hline $\begin{array}{l}\text { Verbeke, A. \& } \\
\text { Forootan, M.Z. } \\
\text { (2012) }\end{array}$ & $\begin{array}{l}\text { Conceptual } \\
\text { paper }\end{array}$ & $\begin{array}{l}12 \text { most cited } \\
\text { papers in M-P } \\
\text { literature of } \\
\text { MNEs and SMEs. } \\
\text { Focus: theoretical } \\
\text { debate }\end{array}$ & $\begin{array}{l}\text { Propose a new M-P conceptual approach and a testing framework } \\
\text { of } 12 \text { subtests, to assess the quality of the M-P empirical literature } \\
\text { to date. } \\
\text { Tests } 1,2 \text {, and } 3 \text { as in Verbeke and Brugman, 2009. } \\
\text { - Test 4: a) changes in M due to changes in home country activity } \\
\text { level; b) isolate the P effect of international operations c) early } \\
\text { versus late entry. } \\
12 \text { most cited studies were poorly conceived and simply cannot } \\
\text { lead to reasonable conclusions on possible M-P linkages. } \\
\text { - Neglect of the MNE's FSAs as the main driving force behind } \\
\text { internationalization strategies and related effects on performance. }\end{array}$ & $\begin{array}{l}\text { Future research should apply } 12 \text { quality } \\
\text { subtests as a tool to reflect and to improve the } \\
\text { proposed study design. }\end{array}$ \\
\hline $\begin{array}{l}\text { Contractor, F. } \\
\text { (2012) }\end{array}$ & $\begin{array}{l}\text { Conceptual } \\
\text { paper }\end{array}$ & $\begin{array}{l}\text { Focus: theoretical } \\
\text { debate }\end{array}$ & $\begin{array}{l}\text { A detailed microanalysis of the benefits, costs, and limits of } \\
\text { international expansion to explain why MNEs exist, in response to } \\
\text { critiques which ask whether any generalizable theory relationship } \\
\text { exists between firm performance (P) and its degree of } \\
\text { multinationality }(\mathrm{M}) \text {. } \\
\text { Propose alternative methodological reasons for the seemingly } \\
\text { contradictory and confusing results of past empirical studies over } \\
30 \text { years. }\end{array}$ & $\begin{array}{l}\text { Future research: seeking contingent } \\
\text { modifications of the general paradigm for } \\
\text { particular strategy situations. } \\
\text { An understanding of cross-section samples and } \\
\text { how or why contingent factors can affect, or } \\
\text { even completely alter, the shape of M-P } \\
\text { relationship, depending on geography, product } \\
\text { diversification, country origin, mode of foreign }\end{array}$ \\
\hline
\end{tabular}


